\title{
Can we explain the observed methane variability after the Mount Pinatubo eruption?
}

\author{
N. Bândă ${ }^{1,2}$, M. Krol ${ }^{3,4,1}$, M. van Weele ${ }^{2}$, T. van Noije ${ }^{2}$, P. Le Sager ${ }^{2}$, and T. Röckmann ${ }^{1}$ \\ ${ }^{1}$ Institute for Marine and Atmospheric Research Utrecht, Utrecht University, Utrecht, The Netherlands \\ ${ }^{2}$ Royal Netherlands Meteorological Institute (KNMI), De Bilt, The Netherlands \\ ${ }^{3}$ Meteorology and Air Quality, Wageningen University and Research Center, Wageningen, The Netherlands \\ ${ }^{4}$ Netherlands Institute for Space Research (SRON), Utrecht, The Netherlands \\ Correspondence to: N. Bândă (n.1.banda@uu.nl)
}

Received: 29 April 2015 - Published in Atmos. Chem. Phys. Discuss.: 10 July 2015

Revised: 9 November 2015 - Accepted: 29 November 2015 - Published: 18 January 2016

\begin{abstract}
The $\mathrm{CH}_{4}$ growth rate in the atmosphere showed large variations after the Pinatubo eruption in June 1991. A decrease of more than $10 \mathrm{ppb} \mathrm{yr}^{-1}$ in the growth rate over the course of 1992 was reported, and a partial recovery in the following year. Although several reasons have been proposed to explain the evolution of $\mathrm{CH}_{4}$ after the eruption, their contributions to the observed variations are not yet resolved. $\mathrm{CH}_{4}$ is removed from the atmosphere by the reaction with tropospheric $\mathrm{OH}$, which in turn is produced by $\mathrm{O}_{3}$ photolysis under UV radiation. The $\mathrm{CH}_{4}$ removal after the Pinatubo eruption might have been affected by changes in tropospheric UV levels due to the presence of stratospheric $\mathrm{SO}_{2}$ and sulfate aerosols, and due to enhanced ozone depletion on Pinatubo aerosols. The perturbed climate after the eruption also altered both sources and sinks of atmospheric $\mathrm{CH}_{4}$. Furthermore, $\mathrm{CH}_{4}$ concentrations were influenced by other factors of natural variability in that period, such as El Niño-Southern Oscillation (ENSO) and biomass burning events. Emissions of $\mathrm{CO}, \mathrm{NO}_{X}$ and non-methane volatile organic compounds (NMVOCs) also affected $\mathrm{CH}_{4}$ concentrations indirectly by influencing tropospheric $\mathrm{OH}$ levels.

Potential drivers of $\mathrm{CH}_{4}$ variability are investigated using the TM5 global chemistry model. The contribution that each driver had to the global $\mathrm{CH}_{4}$ variability during the period 1990 to 1995 is quantified. We find that a decrease of 8 $10 \mathrm{ppb} \mathrm{yr}^{-1} \mathrm{CH}_{4}$ is explained by a combination of the above processes. However, the timing of the minimum growth rate is found 6-9 months later than observed. The long-term decrease in $\mathrm{CH}_{4}$ growth rate over the period 1990 to 1995 is well captured and can be attributed to an increase in $\mathrm{OH}$
\end{abstract}

concentrations over this time period. Potential uncertainties in our modelled $\mathrm{CH}_{4}$ growth rate include emissions of $\mathrm{CH}_{4}$ from wetlands, biomass burning emissions of $\mathrm{CH}_{4}$ and other compounds, biogenic NMVOC and the sensitivity of $\mathrm{OH}$ to NMVOC emission changes. Two inventories are used for $\mathrm{CH}_{4}$ emissions from wetlands, ORCHIDEE and LPJ, to investigate the role of uncertainties in these emissions. Although the higher climate sensitivity of ORCHIDEE improves the simulated $\mathrm{CH}_{4}$ growth rate change after Pinatubo, none of the two inventories properly captures the observed $\mathrm{CH}_{4}$ variability in this period.

\section{Introduction}

Methane $\left(\mathrm{CH}_{4}\right)$ is the second most important anthropogenic greenhouse gas after carbon dioxide $\left(\mathrm{CO}_{2}\right)$. Its evolution in the atmosphere since the beginning of the record of continuous atmospheric $\mathrm{CH}_{4}$ measurements in the 1980s is not fully understood, with large discrepancies between bottom-up and top-down estimates of $\mathrm{CH}_{4}$ sources and sinks (Kirschke et al., 2013). One of the events that affected $\mathrm{CH}_{4}$ concentrations was the eruption of Mt Pinatubo on 15 June 1991, the largest eruption in the last century. The eruption caused perturbations to climate and photochemistry for a few years afterwards. We investigate here the sensitivity of $\mathrm{CH}_{4}$ concentrations to these perturbations and our ability to explain the observed $\mathrm{CH}_{4}$ variations in the atmosphere in the early 1990s. 
After a stable $\mathrm{CH}_{4}$ growth rate of 10 to $13 \mathrm{ppbyr}^{-1}$ in the late 1980s, the growth rate showed large fluctuations in the early 1990s. An increased $\mathrm{CH}_{4}$ growth rate of about $17 \mathrm{ppbyr}^{-1}$ was registered by the NOAA network in 1991, followed by a strong decline in the growth rate during the next year, with values reaching nearly zero (Dlugokencky et al., 1994). The growth rate recovered to $6 \mathrm{ppb} \mathrm{yr}^{-1}$ in 1993. Processes driving these variations could be related to either the $\mathrm{CH}_{4}$ sources or the $\mathrm{CH}_{4}$ sinks.

$\mathrm{CH}_{4}$ is emitted into the atmosphere from anthropogenic activities (fossil fuel production, agriculture and waste treatment), biomass burning, and from natural sources (wetlands, geological activity, termites). The main sink of atmospheric $\mathrm{CH}_{4}$ is the reaction with the hydroxyl radical $(\mathrm{OH})$ in the troposphere, which removes about $80 \%$ of the $\mathrm{CH}_{4}$. Other removal processes are soil uptake, reactions with chlorine $(\mathrm{Cl})$ in both the troposphere and stratosphere, and reactions with $\mathrm{OH}$ and excited oxygen $\left(\mathrm{O}\left({ }^{1} \mathrm{D}\right)\right)$ atoms in the stratosphere. Tropospheric $\mathrm{OH}$ is produced by the photolysis of ozone $\left(\mathrm{O}_{3}\right)$ at wavelengths of $280-320 \mathrm{~nm}$, followed by the reaction of $\mathrm{O}\left({ }^{1} \mathrm{D}\right)$ with water vapour. Therefore the abundance of $\mathrm{OH}$ in the troposphere is sensitive both to the amount of incoming UV radiation and to the water vapour abundance. Tropospheric $\mathrm{OH}$ also reacts with other atmospheric compounds such as carbon monoxide (CO) and non-methane volatile organic compounds (NMVOCs), and is recycled in the presence of nitrogen oxides $\left(\mathrm{NO}_{X}\right)$. Thus, changes in the emissions of $\mathrm{NO}_{X}, \mathrm{CO}$ and NMVOCs also affect the $\mathrm{OH}$ abundance (Lelieveld et al., 2002).

Inter-annual variations in both the sources and sinks of $\mathrm{CH}_{4}$ occurred in the early 1990s. In part, these can be related to the Pinatubo eruption, which caused a decrease in tropospheric temperatures of about $0.5^{\circ} \mathrm{C}$ globally in the two following years (McCormick et al., 1995). The global cooling most likely resulted in a decrease in the $\mathrm{CH}_{4}$ emission rates from wetlands. Methane emissions from wetlands might have also been inhibited by the deposition of volcanic sulfur from the eruption (Gauci et al., 2008).

The removal of $\mathrm{CH}_{4}$ by $\mathrm{OH}$ is a temperature-dependent reaction which was also affected by the temperature decrease after the eruption. $\mathrm{OH}$ production would have further responded to the decrease in water vapour associated with the temperature reduction (Soden et al., 2002). The climate anomaly after Pinatubo might have affected natural emissions of other species as well, such as NMVOC emissions from vegetation, which may in turn have caused changes in $\mathrm{OH}$ and thus the $\mathrm{CH}_{4}$ sink. Changes in $\mathrm{UV}$ radiation due to stratospheric aerosols and stratospheric $\mathrm{O}_{3}$ anomalies would have also affected the removal of $\mathrm{CH}_{4}$ by $\mathrm{OH}$ in the postPinatubo years (Dlugokencky et al., 1996; Bekki et al., 1994; Bândă et al., 2014, from here on referred to as B14). Stratospheric $\mathrm{O}_{3}$ variations in this period were caused by heterogeneous removal on volcanic aerosol particles, by atmospheric transport changes due to the eruption, and by other factors of natural variability (Telford et al., 2009; Bekki and Pyle, 1994).

Another potential effect of the eruption on the $\mathrm{CH}_{4}$ budget is altered transport between the troposphere and the stratosphere due to the stratospheric warming by volcanic particles (Schauffler and Daniel, 1994). $\mathrm{CH}_{4}$ concentrations in the post-Pinatubo period were also affected by natural variability not related to Pinatubo, such as the 11-year solar cycle, the El Niño-Southern Oscillation (ENSO) cycle and biomass burning events. Significant reductions in the anthropogenic emissions from gas production and distribution in the former Soviet Union (FSU) might have occurred in this period (Law and Nisbet, 1996). However, gaps in reporting make the magnitude and timing of these reductions quite uncertain.

Previous bottom-up studies quantified the impact of individual processes on the $\mathrm{CH}_{4}$ abundance, without attempting to solve the whole $\mathrm{CH}_{4}$ budget. Bekki and Law (1997) found compensating effects of temperature on the $\mathrm{CH}_{4}$ emissions and the $\mathrm{CH}_{4}$ removal by $\mathrm{OH}$ on a global scale. Dlugokencky et al. (1996) showed that the increase in both $\mathrm{CH}_{4}$ and $\mathrm{CO}$ mixing ratios in late 1991 and early 1992 could be related to a decrease in $\mathrm{OH}$ due to UV scattering by stratospheric aerosols and UV absorption by sulfur dioxide $\left(\mathrm{SO}_{2}\right)$ from the eruption. A more recent estimate from $\mathrm{B} 14$ finds a decrease of 11.2 and $6.6 \mathrm{Tg}$, respectively, in the $\mathrm{CH}_{4}$ removal in the first and second years following the eruption due to stratospheric sulfur. The above decreases in $\mathrm{CH}_{4}$ removal translate into corresponding increases of 4 and $2 \mathrm{ppb} \mathrm{yr}^{-1}$, respectively, in the $\mathrm{CH}_{4}$ growth rate. Here and in the remainder of the paper, we use the ratio of $2.78 \mathrm{Tg} \mathrm{ppb}^{-1}$ reported by the IPCC (Denman et al., 2007) to convert from $\mathrm{CH}_{4}$ burden changes to growth rate variations. Using a two-dimensional model, Bekki et al. (1994) attributed half of the decrease in $\mathrm{CH}_{4}$ and $\mathrm{CO}$ growth rates in 1992 to stratospheric $\mathrm{O}_{3}$ depletion. Additionally, Dlugokencky et al. (1994) and Law and Nisbet (1996) estimated that a decrease in the gas leak emissions from the FSU could be of the order of $15 \mathrm{Tg} \mathrm{yr}^{-1}$, and would also explain part of the observed decrease in the $\mathrm{CH}_{4}$ growth rate in 1992. Using a four-box model, Schauffler and Daniel (1994) found that an increase in the exchange rate between the stratosphere and troposphere due to volcanic aerosol heating can cause lower $\mathrm{CH}_{4}$ concentrations in the troposphere.

Prior attempts to explain the $\mathrm{CH}_{4}$ variability in this period include inverse modelling studies and a column model study. The inverse modelling studies of Bousquet et al. (2006) and Wang et al. (2004) (B06 and W04 from here on, respectively) find a positive anomaly in the $\mathrm{CH}_{4}$ flux to the atmosphere in 1991, and a negative anomaly in 1992, with a difference of about $30 \mathrm{Tg}$ between the two years. Both studies find a significant contribution from wetland emissions to this anomaly and a small contribution from biomass burning. However, the two studies use $\mathrm{OH}$ variations of opposite sign. The $\mathrm{OH}$ fields in $\mathrm{B} 06$ are determined by methyl chloroform inversions, showing a reduced $\mathrm{OH}$ sink of $\mathrm{CH}_{4}$ 
of about $30 \mathrm{Tg} \mathrm{yr}^{-1}$ over the period 1991 to 1993 compared to 1990. To close the $\mathrm{CH}_{4}$ budget, their anthropogenic and wetland $\mathrm{CH}_{4}$ emissions also show pronounced decreases. When using both $\mathrm{CH}_{4}$ and methyl chloroform to constrain $\mathrm{OH}$, Pison et al. (2013) found a more moderate $\mathrm{OH}$ variability. In W04, OH is parameterised based on chemical and meteorological parameters with coefficients determined from three-dimensional model simulations. W04 find an increase of about $5 \%$ in OH from 1991 to 1993 due to stratospheric $\mathrm{O}_{3}$ depletion. Stratospheric aerosols from the eruption are, however, not included as a parameter in their calculation. Our previous column model study (Bândă et al., 2013) supports a decrease in $\mathrm{OH}$ in the first year after the eruption due to aerosols, temperature and water vapour changes, and a subsequent decrease due to stratospheric $\mathrm{O}_{3}$ depletion. In that study we found that the stratospheric $\mathrm{O}_{3}$ depletion together with changes in anthropogenic emissions could explain a $12 \mathrm{ppbyr}^{-1}$ decrease in 1993 compared to 1991 . However, the one-dimensional model was unable to capture the strong $\mathrm{CH}_{4}$ decrease in 1992.

In the present study, we quantify the combined impact of the drivers of $\mathrm{CH}_{4}$ variability described above in the early 1990s using the TM5 global chemistry and transport model, and we identify the potential gaps in our understanding of the $\mathrm{CH}_{4}$ budget. For the first time, all the known processes that could have significantly contributed to the $\mathrm{CH}_{4}$ variations in the early 1990s are included in a modelling study.

The paper is structured as follows. A description of the TM5 model is presented in Sect. 2.1 and of the simulation set-up in Sect. 2.2. Section 2.3 describes the drivers that have been considered to explain the observed $\mathrm{CH}_{4}$ variability, and Sect 3.1 presents their impact on the simulated $\mathrm{CH}_{4}$ budget. The unexplained $\mathrm{CH}_{4}$ variability is shown in Sect. 3.2, and possible reasons for mismatch between the model and observations are discussed in Sect. 4. Conclusions are drawn in Sect. 5.

\section{Method}

\subsection{Model description}

The TM5 global chemistry and transport model (Huijnen et al., 2010; Williams et al., 2012; van Noije et al., 2014) was used to simulate the chemical composition of the atmosphere during the period 1990 to 1995. The model was run on 60 hybrid sigma-pressure vertical levels and at a horizontal resolution of $3^{\circ} \times 2^{\circ}$ (longitude $\times$ latitude) globally, except for the polar region, where a reduced grid was used for advection in the zonal direction. The model was driven by meteorological fields from the ECMWF ERA-Interim reanalysis (Dee et al., 2011). The gas-phase chemistry scheme is based on a modified version of the Carbon Bond Mechanism 4 (Houweling et al., 1998). Photolysis frequencies are calculated by the on-line parameterisation scheme based on
Williams et al. (2006). To account for missing $\mathrm{O}_{3}$ chemistry in the stratosphere, $\mathrm{O}_{3}$ is nudged to the multi-sensor reanalysis data (MSR; van der A et al., 2010) above the $45 \mathrm{hPa}$ level in the tropics $\left(30^{\circ} \mathrm{S}-30^{\circ} \mathrm{N}\right)$ and above the $90 \mathrm{hPa}$ level in the extra-tropics. $\mathrm{CH}_{4}$ is also nudged above these pressure levels to climatological values from Grooß and Russell III (2005) to compensate for possible errors in stratospheric chemistry, specifically the loss of $\mathrm{CH}_{4}$ by $\mathrm{OH}, \mathrm{Cl}$ and $\mathrm{O}\left({ }^{1} \mathrm{D}\right)$. The performance of TM5 in simulating atmospheric chemistry is presented in Huijnen et al. (2010) and van Noije et al. (2014). The conclusions of these studies remain valid with the current set-up.

The M7 modal scheme (Vignati et al., 2004; Aan de Brugh et al., 2011) is used to simulate aerosol microphysics. M7 simulates the following aerosol types: sulfate $\left(\mathrm{SO}_{4}\right)$, black carbon (BC), organic carbon (OC), sea salt and mineral dust. In addition, TM5 calculates ammonium and nitrate partitioning between gas phase and aerosols using the Equilibrium Simplified Aerosol Model (EQSAM; Metzger et al., 2002), and accounts for methyl sulfonic acid (MSA). The aerosols are coupled to the radiative transfer scheme that is used to calculate photolysis frequencies. Some adjustments to the M7 default set-up have been applied in order to realistically simulate stratospheric volcanic aerosols, as described in B14. This set-up has been used in the aforementioned paper to model $\mathrm{SO}_{2}$ and sulfate aerosols from the Pinatubo eruption, and to infer their effect on photolysis frequencies.

Here we use the new massively parallel model version TM5-mp. The new MPI parallelisation does not influence the model results, but brings a significant speedup of the model runs by allowing us to use more computing cores more efficiently. A few additional updates have been incorporated into the model compared to the version used in B14. Convective fluxes used for tracer transport are now read from the ERA-Interim input data, instead of calculating them with the Tiedtke scheme (Tiedtke, 1989). Heterogeneous removal of $\mathrm{N}_{2} \mathrm{O}_{5}$ on aerosol and cloud particles was updated according to Huijnen et al. (2014). The $\mathrm{CH}_{4}$ surface nudging timescale has also been adjusted. We now use a nudging timescale of 10 days instead of 3 days in B14. By comparing the budget terms and concentrations of simulations with the different nudging timescales, we find that both nudging timescales give a similar performance in simulating the $\mathrm{CH}_{4}$ concentrations and inter-annual variability (IAV). Although similar global nudging values are found for the two simulations, the local nudging amount is 2 to 3 times larger using a 3-day nudging. Therefore we find that a 10-day nudging timescale is more appropriate for inferring $\mathrm{CH}_{4}$ budget mismatches based on monthly observations, allowing for synoptic-scale variability in $\mathrm{CH}_{4}$ concentrations (Dentener et al., 2003). Finally, some of the emission inventories used here differ from the ones used in B14, and are described below. We verified that the model updates did not cause any significant differences in modelled $\mathrm{SO}_{2}$ and stratospheric aerosols compared to the results presented in B14. 
Table 1. Annual mean $\mathrm{CH}_{4}$ sources and sinks, and their inter-annual variability (IAV). All values are in $\mathrm{Tg} \mathrm{yr}^{-1}$.

\begin{tabular}{|c|c|c|c|c|c|c|c|c|c|}
\hline Category & $\begin{array}{l}\text { Inventory } \\
\text { or simulation }\end{array}$ & 1990 & 1991 & 1992 & 1993 & 1994 & 1995 & Mean & IAV \\
\hline Natural wetlands & $\begin{array}{l}\text { ORCHIDEE } \\
\text { LPJ }\end{array}$ & $\begin{array}{l}273.9 \\
167.4\end{array}$ & $\begin{array}{l}276.6 \\
163.9\end{array}$ & $\begin{array}{l}251.7 \\
161.9\end{array}$ & $\begin{array}{l}262.1 \\
165.6\end{array}$ & $\begin{array}{l}272.1 \\
167.7\end{array}$ & $\begin{array}{l}260.8 \\
169.3\end{array}$ & $\begin{array}{l}266.2 \\
166.1\end{array}$ & $\begin{array}{l}11.9 \\
2.6\end{array}$ \\
\hline Natural other & HYMN & 43.0 & 43.0 & 43.0 & 43.0 & 43.0 & 43.0 & 43.0 & - \\
\hline Anthropogenic & EDGAR & 256.7 & 256.2 & 257.2 & 256.4 & 257.3 & 260.0 & 257.3 & 1.2 \\
\hline Biomass burning & RETRO & 19.5 & 21.2 & 23.0 & 17.8 & 20.4 & 16.5 & 19.7 & 3.0 \\
\hline Trop $\mathrm{CH}_{4}+\mathrm{OH}$ & $\begin{array}{l}\text { Base1 } \\
\text { Base2 }\end{array}$ & $\begin{array}{l}489.8 \\
487.9\end{array}$ & $\begin{array}{l}489.4 \\
487.5\end{array}$ & $\begin{array}{l}483.7 \\
482.8\end{array}$ & $\begin{array}{l}505.4 \\
504.6\end{array}$ & $\begin{array}{l}512.0 \\
511.2\end{array}$ & $\begin{array}{l}517.8 \\
517.1\end{array}$ & $\begin{array}{l}499.7 \\
498.5\end{array}$ & $\begin{array}{l}8.1 \\
7.9\end{array}$ \\
\hline Stratospheric sink & $\begin{array}{l}\text { Base1 } \\
\text { Base2 }\end{array}$ & $\begin{array}{l}35.1 \\
33.0\end{array}$ & $\begin{array}{l}39.2 \\
37.2\end{array}$ & $\begin{array}{l}39.8 \\
38.8\end{array}$ & $\begin{array}{l}40.3 \\
39.4\end{array}$ & $\begin{array}{l}42.0 \\
41.3\end{array}$ & $\begin{array}{l}41.6 \\
40.8\end{array}$ & $\begin{array}{l}39.7 \\
38.4\end{array}$ & $\begin{array}{l}1.5 \\
1.8\end{array}$ \\
\hline Soil sink & $\begin{array}{l}\text { Base1 } \\
\text { Base2 }\end{array}$ & $\begin{array}{l}29.2 \\
27.1\end{array}$ & $\begin{array}{l}30.4 \\
26.8\end{array}$ & $\begin{array}{l}26.3 \\
27.0\end{array}$ & $\begin{array}{l}28.5 \\
27.2\end{array}$ & $\begin{array}{l}26.4 \\
26.9\end{array}$ & $\begin{array}{l}25.5 \\
27.5\end{array}$ & $\begin{array}{l}27.7 \\
27.1\end{array}$ & $\begin{array}{l}2.1 \\
0.3\end{array}$ \\
\hline Nudging & $\begin{array}{l}\text { Base1 } \\
\text { Base2 }\end{array}$ & $\begin{array}{c}-11.3 \\
88.8\end{array}$ & $\begin{array}{l}-15.1 \\
89.3\end{array}$ & $\begin{array}{c}-18.9 \\
68.2\end{array}$ & $\begin{array}{c}3.5 \\
98.5\end{array}$ & $\begin{array}{c}23.1 \\
120.0\end{array}$ & $\begin{array}{c}11.9 \\
100.1\end{array}$ & $\begin{array}{l}-1.1 \\
94.1\end{array}$ & $\begin{array}{l}12.4 \\
18.7\end{array}$ \\
\hline
\end{tabular}

Table 1 lists the $\mathrm{CH}_{4}$ source and sink categories, the inventories used, and their yearly global mean and variability over the period 1990 to 1995 . Two inventories for $\mathrm{CH}_{4}$ emissions from wetlands are employed to investigate the uncertainty in these emissions. We use the ORCHIDEE (Organising Carbon and Hydrology In Dynamic Ecosystems land surface model) emissions from the WETCHIMP intercomparison project (Wania et al., 2013) and LPJ (Lund-Potsdam-Jena dynamic global model) emissions from the Hydrogen, Methane and Nitrous oxide (HYMN) project (Spahni et al., 2011). Other natural $\mathrm{CH}_{4}$ monthly emissions from wild animals and termites were also used as compiled in $\mathrm{HYMN}$. $\mathrm{CH}_{4}$ soil removal rates from the LPJ inventory were applied. Anthropogenic emissions of $\mathrm{CH}_{4}, \mathrm{CO}, \mathrm{NO}_{X}, \mathrm{NMVOC}, \mathrm{SO}_{2}$ and ammonia $\left(\mathrm{NH}_{3}\right)$ were taken from the EDGAR4.2 inventory, except for the transport sector, for which EDGAR4.1 was used. Decadal anthropogenic emissions of $\mathrm{BC}$ and $\mathrm{OC}$ were taken from the historical AR5 emission inventory (Lamarque et al., 2010). Biomass burning emissions of $\mathrm{CH}_{4}, \mathrm{CO}$, NMVOC, $\mathrm{NO}_{X}, \mathrm{SO}_{2}$ and $\mathrm{NH}_{3}$ are used from the RETRO inventory (Schultz et al., 2008). Production of $\mathrm{NO}_{X}$ by lightning and emissions of dimethyl sulfide (DMS), sea salt and dust are calculated online (Huijnen et al., 2010; Vignati et al., 2010; van Noije et al., 2014). Monthly biogenic emissions of $\mathrm{CO}, \mathrm{NH}_{3}$ and NMVOC were taken from the MEGAN inventory (Sindelarova et al., 2014). Climatological emissions from the MACC inventory are used for continuous volcanic $\mathrm{SO}_{2}$ (Andres and Kasgnoc, 1998) and biogenic $\mathrm{NO}_{X}$ emissions.

\subsection{Simulation set-up}

We designed a series of simulations with the aim of quantifying the impact of specific processes on the tropospheric $\mathrm{CH}_{4}$ concentrations. The difference between two simulations, one including and one excluding a specific driver, is used to quantify the effect of that driver. For instance, we calculate the effect of IAV in meteorology on tropospheric $\mathrm{CH}_{4}$ as the difference of a simulation that includes varying meteorological fields and a simulation that fixes meteorological fields to 1990 values. Two sets of simulations were performed for seven drivers of $\mathrm{CH}_{4}$ variability for the period 1990 to 1995 , as outlined in Table 2.

As described in B14, we use a two-step set-up to simulate realistic $\mathrm{CH}_{4}$ concentrations. In a first simulation of the Base1 and Base2 scenarios, in which all drivers of $\mathrm{CH}_{4}$ variability are included, we nudge $\mathrm{CH}_{4}$ mixing ratios in the lowest $2 \mathrm{~km}$ of the model towards measured mixing ratios from background sites. This allows us to account for uncertainties in sources and sinks of $\mathrm{CH}_{4}$ and to avoid a long-term drift of mixing ratios compared to observations. This set-up is particularly important for the second simulation set using the lower LPJ wetland emissions, where nearly $100 \mathrm{Tg} \mathrm{yr}^{-1}$ additional source or reduced sink is needed to close the $\mathrm{CH}_{4}$ budget. The nudging is performed as follows. The northsouth gradient in the $\mathrm{CH}_{4}$ mixing ratio is reconstructed by interpolating the measured $\mathrm{CH}_{4}$ monthly mean mixing ratios at the background stations South Pole, Cape Grim, Mauna Loa, Niwot Ridge, and Barrow. In this way a realistic zonal mean $\mathrm{CH}_{4}$ distribution is obtained from the observations, which is then compared to the modelled concentrations at the dateline. The concentrations in the whole zonal band are 
then adjusted based on this comparison. The amount of $\mathrm{CH}_{4}$ needed to compensate for the difference between the model and observation-based north-south gradient in $\mathrm{CH}_{4}$ is stored on a monthly basis for each $10^{\circ}$ latitude band. In the second step, $\mathrm{CH}_{4}$ is no longer constrained by observations, but instead the nudging amount calculated in the first step is applied as an emission in all scenarios. In B14 we used this nudging to scale the $\mathrm{CH}_{4}$ emissions in each $10^{\circ}$ latitude band. In these simulations, we observed slight time shifts in the derived $\mathrm{CH}_{4}$ growth rates in the second step compared to the first step. To obtain an almost perfect match between the simulated $\mathrm{CH}_{4}$ concentrations of the two steps, in the present study we apply the nudging homogeneously over the latitude band and in the lowest $2 \mathrm{~km}$ from the surface. This twostep set-up enables us to model realistic $\mathrm{CH}_{4}$ concentrations, and at the same time allowing them to respond to changes in emissions or photochemistry. The nudging term that is needed to force the Base1 and Base2 simulations to background atmospheric observations indicates in which latitude bands sources and sinks are unbalanced when all drivers of $\mathrm{CH}_{4}$ variability are included. These mismatches will be further analysed in Sect. 3.2. Validation results for this two-step set-up are shown in Appendix A.

The first simulation set (Set I in Table 2) uses the ORCHIDEE inventory for natural $\mathrm{CH}_{4}$ emissions from wetlands, while the second set of simulations uses the LPJ inventory. The Base1 simulation from the first simulation set accounts for all drivers of $\mathrm{CH}_{4} \mathrm{IAV}$ in the model, including modelled stratospheric sulfur, varying amounts of stratospheric $\mathrm{O}_{3}$, ERA-Interim fields for temperature and humidity, and emission variations of $\mathrm{CH}_{4}$ and other species. Emissions of $\mathrm{SO}_{2}$ into the stratosphere by the Pinatubo eruption of $18.5 \mathrm{Tg} \mathrm{SO} \mathrm{S}_{2}$ were considered, and the $\mathrm{SO}_{2}$ subsequently reacts with $\mathrm{OH}$ to form aerosols. In the other simulations, we fix different variables in the model to investigate their effect on $\mathrm{CH}_{4}$ concentrations. In all simulations except for the Base1 simulation, we removed the effects of Pinatubo $\mathrm{SO}_{2}$ and sulfate, because using a different meteorology or $\mathrm{O}_{3}$ column might lead to different $\mathrm{SO}_{2}$ and aerosol fields. By using this set-up, we minimise the nonlinearities between drivers of $\mathrm{CH}_{4}$ variability. In FixMeteo1 and FixOzone1, we additionally used the meteorology and, respectively, the stratospheric $\mathrm{O}_{3}$ of the year 1990 for the whole length of the simulation. In the FixWetl1 simulation we used constant $\mathrm{CH}_{4}$ emissions from wetlands and $\mathrm{CH}_{4}$ soil uptake rates from the year 1990. Simulation FixEmis1 used anthropogenic and biomass burning emissions of $\mathrm{CH}_{4}$ and other species from the year 1990 . Biogenic emissions of $\mathrm{CO}, \mathrm{NMVOC}$ and $\mathrm{NO}_{X}$ are also fixed to 1990 in FixEmis. Finally, to infer the combined effect of all seven drivers of $\mathrm{CH}_{4}$ variability, simulation FixAll1 is performed, where all drivers of variability are fixed to 1990 values. This allows us to quantify the possible effect of nonlinearities, as discussed in Appendix B.

To test the impact of using a different inventory for $\mathrm{CH}_{4}$ emissions from wetlands, a second set of simulations (Set II in Table 2) is performed using LPJ emissions. The second set of simulations consists of simulations Base2, NoPinS2 and FixWet12, which are equivalent to Base1, NoPinS1 and FixWetl1, respectively, of the first set. The Base2 simulation is similar to the PinS simulation in B14, extended for three more years. The LPJ emissions and soil uptake rates from the year 1990 are used in FixWetl2 throughout the simulation.

\subsection{Drivers of $\mathrm{CH}_{4}$ variability}

In this section we present the drivers of $\mathrm{CH}_{4}$ variability in our model. The factors that affect the $\mathrm{CH}_{4}$ sinks are stratospheric sulfur, stratospheric $\mathrm{O}_{3}$, changes in meteorology, and emissions of $\mathrm{CO}$ and NMVOC. The $\mathrm{CH}_{4}$ emissions for different sectors are also presented. We show model results for sulfate aerosol, while for other drivers of $\mathrm{CH}_{4}$ variability we give a quantitative description of the input data. Their impact on the $\mathrm{CH}_{4}$ concentration is analysed in Sect. 3.1.

The main drivers of $\mathrm{CH}_{4}$ variability in our model for the period 1990 to 1995 are shown in Fig. 1. All variables have been averaged with a 12-month running mean to remove the seasonal cycle. The globally averaged stratospheric aerosol optical depth (AOD) is shown in Fig. 1a. The simulated AOD values were validated against measurements in B14. A global maximum AOD of 0.16 is simulated in early 1992. The aerosols remained in the stratosphere for a few years, with the AOD returning to pre-eruption levels towards the end of 1994.

Figure $1 \mathrm{~b}$ presents the average stratospheric $\mathrm{O}_{3}$ above $150 \mathrm{hPa}$ between $60^{\circ} \mathrm{S}$ and $60^{\circ} \mathrm{N}$ from the MSR data set (van der $\mathrm{A}$ et al., 2010). High-latitude $\mathrm{O}_{3}$ anomalies are not taken into account here because the $\mathrm{CH}_{4}$ is mainly oxidised in the tropics and at mid-latitudes during summer. A number of processes caused variations in stratospheric $\mathrm{O}_{3}$ in the period 1990 to 1995 . The 11-year cycle in solar radiation determined an overall decrease of $2.5 \%$ (6 Dobson units - DU) in the $\mathrm{O}_{3}$ column over this period. The quasi-biennial oscillation (QBO) in stratospheric winds caused an additional IAV of about $1 \%$ (2DU). In addition to these natural cycles, enhanced $\mathrm{O}_{3}$ depletion occurred in 1992 to 1994 due to dynamical changes and heterogeneous chemistry associated with the presence of Pinatubo sulfate particles in the stratosphere (Telford et al., 2009; Aquila et al., 2013). This caused a $3.5 \%$ (8DU) decrease in stratospheric $\mathrm{O}_{3}$ from 1991 to early 1993, with the largest perturbations observed at northern mid-latitudes. A smaller decrease of about $4 \mathrm{DU}$ is found in the tropics (Shepherd et al., 2014). The effect of observed $\mathrm{O}_{3}$ variations on $\mathrm{CH}_{4}$ concentrations is investigated in Sect. 3.1. We do not separate in this study the effect of Pinatubo on stratospheric $\mathrm{O}_{3}$ from other factors of $\mathrm{O}_{3}$ variability.

A global-scale decrease in surface temperature was registered in 1992 caused by the decrease in surface shortwave radiation due to the volcanic aerosols. The effect of the eruption was partly counteracted by the 1992-1993 El Niño (McCormick et al., 1995). In our ERA-Interim input data we find 
Table 2. Set-up of the simulations, including the $\mathrm{CH}_{4}$ wetland inventory used and the drivers of $\mathrm{CH}_{4}$ included in each simulation. The crosses indicate that the variability of a certain driver is included in the simulation. Otherwise the driver is not included (in the case of Pinatubo $\mathrm{SO}_{2}$ and aerosol) or 1990 values are used throughout the simulation.

\begin{tabular}{|c|c|c|c|c|c|c|c|c|}
\hline \multirow[b]{2}{*}{$\begin{array}{l}\text { Simulation } \\
\text { name }\end{array}$} & \multirow[b]{2}{*}{$\begin{array}{l}\text { Inventory for } \\
\mathrm{CH}_{4} \text { emissions } \\
\text { from wetlands }\end{array}$} & \multicolumn{7}{|c|}{ Drivers of $\mathrm{CH}_{4}$ variability included } \\
\hline & & $\begin{array}{c}\text { Pinatubo } \mathrm{SO}_{2} \\
\text { and aerosol }\end{array}$ & $\begin{array}{c}\text { Stratospheric } \\
\mathrm{O}_{3}\end{array}$ & Meteorology & $\begin{array}{c}\mathrm{CH}_{4} \\
\text { wetland } \\
\text { emissions }\end{array}$ & $\begin{array}{c}\text { Natural } \\
\text { emissions of } \mathrm{CO}, \\
\text { NMVOC and } \mathrm{NH}_{3}\end{array}$ & $\begin{array}{c}\text { Anthropogenic } \\
\text { emissions of } \mathrm{CH}_{4} \text { and } \\
\text { other compounds }\end{array}$ & $\begin{array}{l}\text { Biomass burning } \\
\text { emissions of } \mathrm{CH}_{4} \text { and } \\
\text { other compounds }\end{array}$ \\
\hline \multicolumn{9}{|c|}{ Set I } \\
\hline Base1 & ORCHIDEE & $\mathrm{X}$ & $\mathrm{X}$ & $\mathrm{X}$ & $\mathrm{X}$ & $\mathrm{X}$ & $\mathrm{X}$ & $\mathrm{X}$ \\
\hline NoPinS1 & ORCHIDEE & & $\mathrm{X}$ & $\mathrm{x}$ & $\mathrm{X}$ & $\mathrm{X}$ & $\mathrm{X}$ & $\mathrm{X}$ \\
\hline FixOzone1 & ORCHIDEE & & & $\mathrm{X}$ & $\mathrm{X}$ & $\mathrm{X}$ & $\mathrm{X}$ & $\mathrm{X}$ \\
\hline FixMeteo1 & ORCHIDEE & & $\mathrm{X}$ & & $\mathrm{X}$ & $\mathrm{x}$ & $\mathrm{X}$ & $\mathrm{X}$ \\
\hline FixWet11 & ORCHIDEE & & $\mathrm{X}$ & $\mathrm{X}$ & & $\mathrm{X}$ & $\mathrm{X}$ & $\mathrm{X}$ \\
\hline FixEmis1 & ORCHIDEE & & $\mathrm{X}$ & $\mathrm{X}$ & $\mathrm{x}$ & & & \\
\hline FixAll1 & ORCHIDEE & & & & & & & \\
\hline \multicolumn{9}{|c|}{ Set II } \\
\hline Base2 & LPJ & $\mathrm{X}$ & $\mathrm{X}$ & $\mathrm{X}$ & $\mathrm{X}$ & $\mathrm{X}$ & $\mathrm{X}$ & $\mathrm{X}$ \\
\hline NoPinS2 & LPJ & & $\mathrm{X}$ & $\mathrm{X}$ & $\mathrm{x}$ & $\mathrm{X}$ & $\mathrm{X}$ & $\mathrm{X}$ \\
\hline FixWet12 & LPJ & & $\mathrm{X}$ & $X$ & $X$ & & $X$ & $X$ \\
\hline
\end{tabular}

a global mean temperature decrease of $0.5^{\circ} \mathrm{C}$ in the free troposphere and of $0.3^{\circ} \mathrm{C}$ at the surface between 1990 and 1992 , followed by a temperature recovery in 1994 (Fig. 1c). The temperature decrease was associated with a $3 \%$ decrease in tropospheric water vapour.

Other meteorological changes in this period, such as dynamics or cloudiness, might have also affected the stratosphere-troposphere exchange of $\mathrm{CH}_{4}$ and the $\mathrm{CH}_{4}$ removal by $\mathrm{OH}$. Although these other meteorological parameters are not presented in this section, their potential effects on $\mathrm{CH}_{4}$ are included when comparing the NoPinS and FixMeteo simulations.

Variability in emissions of chemical species might have determined changes in $\mathrm{OH}$ concentrations. Global $\mathrm{CO}$ and $\mathrm{NO}_{X}$ emissions have a similar evolution over the period 1990 to 1996 , mainly driven by variations in biomass burning (Fig. 1d). A large biomass burning event in 1992 leads to an increase of $100 \mathrm{TgCO} \mathrm{yr}^{-1}$ in $\mathrm{CO}$ emissions and of $1.5 \mathrm{Tg} \mathrm{NO}_{X} \mathrm{yr}^{-1}$ in 1992, and a decrease of similar magnitude 1 year afterwards. The $\mathrm{NO}_{X}$ emissions remain relatively constant throughout the rest of the period, while $\mathrm{CO}$ emissions decrease by about 50 Tg between 1990 and 1996 . Biogenic emissions of NMVOC can also influence $\mathrm{CH}_{4}$ concentrations indirectly through their reaction with $\mathrm{OH}$. Isoprene, the NMVOC species with the largest emission rate in the atmosphere, is mainly produced by plants. Biogenic isoprene emissions are sensitive to changes in temperature, precipitation and radiation, and were likely affected by the Pinatubo eruption (Telford et al., 2010; Wilton et al., 2011). Global emissions of isoprene, shown in Fig. 1e, given by the MEGAN inventory are 640-660 $\mathrm{Tg} \mathrm{yr}^{-1}$ during 1990 and 1991. Over the course of 1992, the isoprene emissions decrease by about $70 \mathrm{Tg} \mathrm{yr}^{-1}$, remaining at about 580 $600 \mathrm{Tg} \mathrm{yr}^{-1}$ throughout the simulation period.

Changes in the main $\mathrm{CH}_{4}$ emission categories are presented in Fig. 1f-h. Inter-annual variability in total $\mathrm{CH}_{4}$ emissions is dominated by emissions from wetlands and biomass burning. Both the LPJ and ORCHIDEE inventories show decreased $\mathrm{CH}_{4}$ emissions from wetlands in 1991-1993. However, the exact timing and magnitude vary considerably between the two inventories, as well as the global emission amount and IAV. The ORCHIDEE inventory finds on average $266 \mathrm{Tg} \mathrm{yr}^{-1} \mathrm{CH}_{4}$ global emissions from wetlands, with inter-annual variability of $11.9 \mathrm{Tg} \mathrm{yr}^{-1}$ (see Table 1 ). The largest anomaly in this period is found after the Pinatubo eruption, with a decrease of $30 \mathrm{Tg} \mathrm{yr}^{-1}$ between the time of the eruption and 1 year afterwards. The LPJ inventory shows global wetland emissions of $166 \mathrm{Tg} \mathrm{yr}^{-1}$ with an IAV of $2.6 \mathrm{Tg} \mathrm{yr}^{-1}$. A decrease of $8 \mathrm{Tg} \mathrm{yr}^{-1}$ in $\mathrm{CH}_{4}$ emissions from wetlands is found by LPJ during the year of the eruption, and a recovery starting from early 1992 . Wetland extent has been shown to be important for simulating the IAV in wetland emissions, and might be a reason for the large differences between the two models (Ringeval et al., 2010; Spahni et al., 2011). ORCHIDEE simulates wetland extent interactively through the coupling to the TOPMODEL hydrology, while LPJ uses fixed wetland extent. The ORCHIDEE global emissions have been shown to be larger than those of other models from the WETCHIMP intercomparison study, having a high sensitivity to changes in $\mathrm{CO}_{2}$, temperature and precipitation (Melton et al., 2013). 

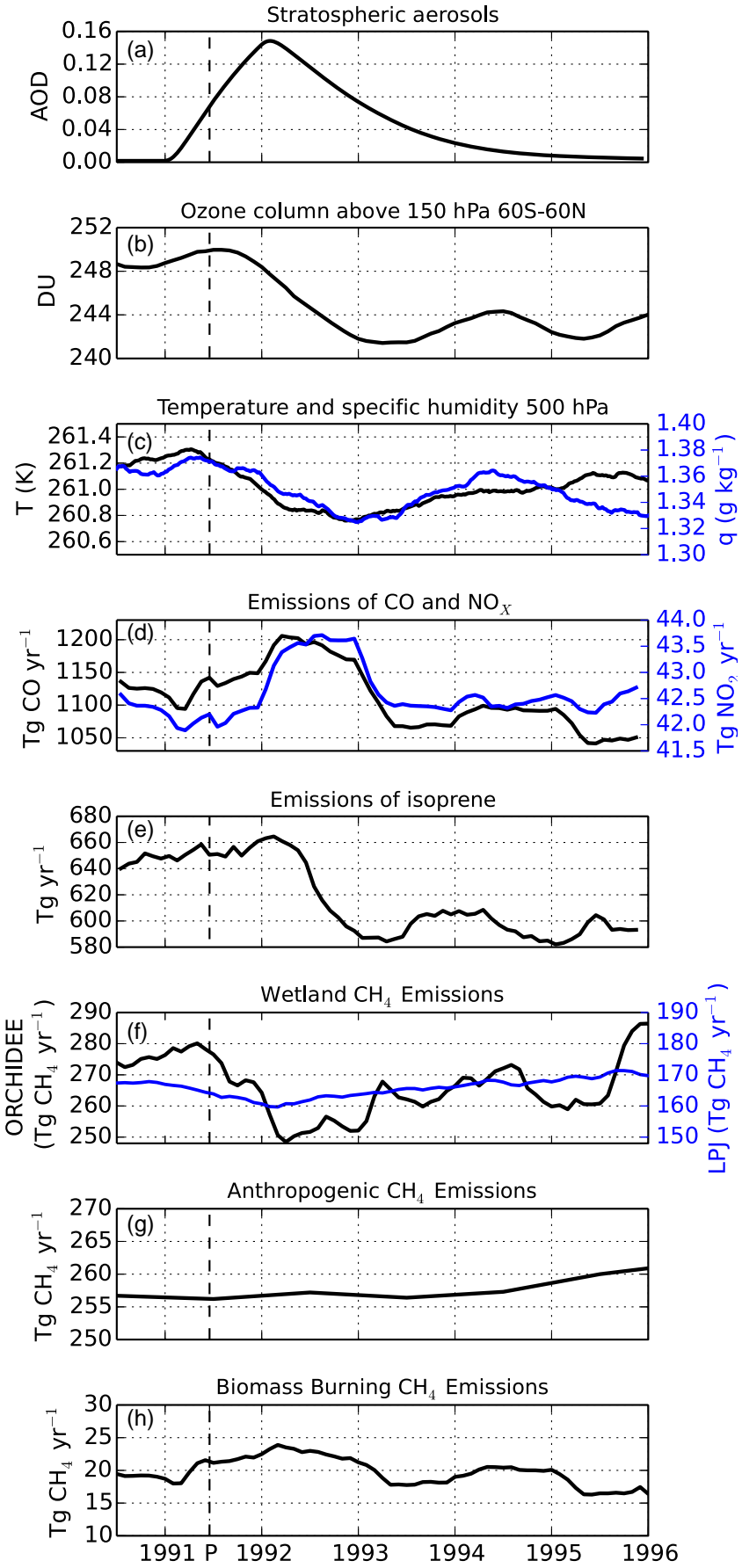

Figure 1. The drivers of $\mathrm{CH}_{4} \mathrm{IAV}$ in the early 1990 s considered in this study. The black dashed line denotes the timing of the Pinatubo eruption.

We used in our simulations the biomass burning emissions of $\mathrm{CH}_{4}$ reported by the RETRO inventory, which amount to a global mean of $19.7 \mathrm{Tg} \mathrm{yr}^{-1}$ over this period, with an IAV of $2.6 \mathrm{Tg} \mathrm{yr}^{-1}$ and higher emissions in the years 1991, 1992 and 1994. The IAV in RETRO is determined from national fire reports, and from climate, soil moisture and carbon pool data used in the Reg-FIRM regional fire model (Schultz et al., 2008). Global anthropogenic emissions were quite stable at 256 to $261 \mathrm{Tg} \mathrm{yr}^{-1}$ during 1990 to 1995 , according our input data based on EDGAR 4.2 and REAS 1 emission inventories, with an IAV of $1.2 \mathrm{Tg} \mathrm{yr}^{-1}$ and an increase towards the end of the period. More significant changes occurred at a regional level, with an overall increase in emissions in SouthEast Asia, and a decrease in Europe, North America and the FSU in this time period. Note, however, that inverse modelling studies report significantly higher total anthropogenic $\mathrm{CH}_{4}$ emissions for this time period than the bottom-up inventories, exceeding $350 \mathrm{Tg} \mathrm{yr}^{-1}$ (Kirschke et al., 2013; Pison et al., 2013).

\section{Results}

\subsection{Explained $\mathrm{CH}_{4}$ variability}

By taking differences between the budget terms of the simulations in Table 2, we are able to infer the effect of each driver of $\mathrm{CH}_{4}$ variability described above. Figure 2 shows zonally averaged differences in $\mathrm{CH}_{4}$ sources and sinks between the different simulations, vertically integrated over the troposphere. These differences are integrated up to a tropopause level defined here as a function of latitude, as recommended in Lawrence et al. (2001).

Absorption of UV radiation by volcanic $\mathrm{SO}_{2}$ and $\mathrm{UV}$ scattering by sulfate aerosol are both included in the Base 1 simulation, and lead to a decrease in UV radiation entering the troposphere. As shown in B14, the effect of stratospheric aerosols on global $\mathrm{CH}_{4}$ is dominating and longer lived in comparison to the effect of $\mathrm{SO}_{2}$ absorption. A decrease in the $\mathrm{CH}_{4}$ sink is depicted in Fig. 2a due to stratospheric sulfur, calculated as the difference between the Base 1 and NoPinS1 simulations. The impact of stratospheric sulfur is strongest in the months after the eruption in the tropical region, with decreases in the zonal mean $\mathrm{CH}_{4}$ sink of 2 to $5 \mathrm{mg} \mathrm{m}^{-2}$ month $^{-1}$. Starting from 1993, the difference in the $\mathrm{CH}_{4}$ sink due to stratospheric sulfur decreases below $1 \mathrm{mg} \mathrm{m}^{-2}$ month $^{-1}$ globally.

Stratospheric $\mathrm{O}_{3}$ decreased in the tropical region in 1991 to 1995 compared to 1990 . A slight increase in stratospheric $\mathrm{O}_{3}$ was observed in 1991 in the southern mid-latitudes because of an increase in the strength of the Brewer-Dobson circulation due to stratospheric heating by Pinatubo aerosols (Aquila et al., 2013). Figure $2 \mathrm{~b}$ shows that these stratospheric $\mathrm{O}_{3}$ changes led to variations in the $\mathrm{OH}$ sink of $\mathrm{CH}_{4}$ between -5 and $+10 \mathrm{mg} \mathrm{m}^{-2}$ month $^{-1}$ in the period 1991 to 1996 . Decreases in the $\mathrm{CH}_{4}$ sink of up to $5 \mathrm{mg} \mathrm{m}^{-2}$ month $^{-1}$ are modelled in 1991 in the extra-tropics, compensated by increases of similar magnitude in the equatorial region. From 1992 to 1996, reduced stratospheric $\mathrm{O}_{3}$ levels caused increases in the $\mathrm{CH}_{4}$ sink in the equatorial band, the northern tropics and part of the northern mid-latitudes. An increase in 

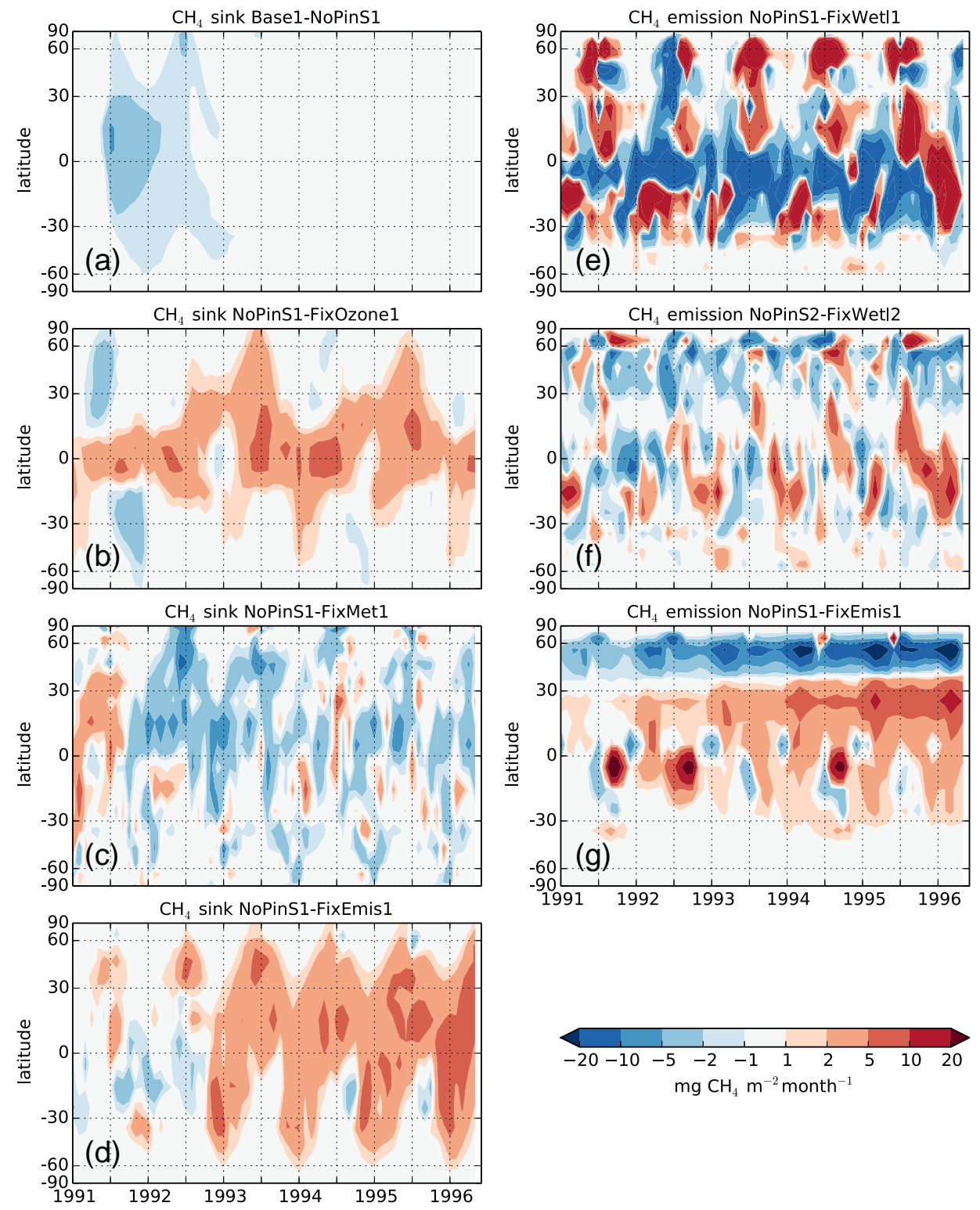

Figure 2. Zonal mean differences in the $\mathrm{CH}_{4}$ budget terms caused by the different drivers of $\mathrm{CH}_{4}$ variability, vertically integrated over the troposphere. Changes in the $\mathrm{CH}_{4}$ sink by the reaction with $\mathrm{OH}$ are shown for the effects of (a) stratospheric sulfur, (b) stratospheric ozone, (c) meteorology and (d) emissions of $\mathrm{CO}, \mathrm{NO}_{X}$ and NMVOC. $\mathrm{CH}_{4}$ emission changes are shown for wetlands from (e) ORCHIDEE and (f) LPJ, and (g) for biomass burning and anthropogenic sectors. The years on the $x$ axis in this and later figures refer to the start of the year.

the $\mathrm{CH}_{4}$ sink of more than $5 \mathrm{mg} \mathrm{m}^{-2}$ month $^{-1}$ is modelled in the northern tropics in the summers of 1993, 1994 and 1995.

The decrease in temperature and water vapour following the eruption led to a decrease in both $\mathrm{OH}$ production and the rate of reaction between $\mathrm{OH}$ and $\mathrm{CH}_{4}$. Our model results show that variations in meteorology caused decreases in the $\mathrm{CH}_{4}$ sink of 2 to $10 \mathrm{mg} \mathrm{m}^{-2}$ month $^{-1}$ in the northern tropical region during September 1991 to March 1993, and in the northern mid-latitudes during the summers of 1992 and 1993 (Fig. 2c).
Variations in emissions of other species indirectly affect $\mathrm{CH}_{4}$ concentrations through the $\mathrm{CH}_{4}$ sink. On the one hand, $\mathrm{CO}$ and NMVOC emissions decrease $\mathrm{OH}$ concentrations because of their reaction with $\mathrm{OH}$. Recycling of $\mathrm{OH}$, on the other hand, increases due to $\mathrm{NO}_{X}$ emissions. Anthropogenic activity and biomass burning events lead to emissions of all these compounds. In addition, the difference between NoPinS and FixEmis also includes changes in biogenic emissions of CO and NMVOC that are sensitive to climate variations (Sindelarova et al., 2014). The overall effect on $\mathrm{OH}$ is determined by the relative increases in total emissions of 
$\mathrm{CO}$ and NMVOC compared to total $\mathrm{NO}_{X}$ emissions (Dalsøren and Isaksen, 2006). The $\mathrm{OH}$ variability due to changes in emissions is shown in Fig. 2d. Particularly large decreases in emissions of $\mathrm{CO}$ from biomass burning and in biogenic NMVOC emissions in our input data occurred between 1992 and 1993, leading to an increase of 3 to $5 \mathrm{mg} \mathrm{m}^{-2}$ month $^{-1}$ in the $\mathrm{CH}_{4}$ sink.

Figure $2 \mathrm{e}$ and $\mathrm{f}$ show differences in wetland emission strength with respect to the year 1990 for the ORCHIDEE and LPJ emission inventories. These emission differences are often larger that those found for the $\mathrm{CH}_{4}$ sink, but they are of shorter duration and more localised. The most striking difference between the $\mathrm{CH}_{4}$ emission variations in the LPJ and in the ORCHIDEE inventories is their magnitude. While the magnitudes of LPJ differences compared to 1990 have values mostly between -10 and $10 \mathrm{mg} \mathrm{m}^{-2}$ month $^{-1}$, the ORCHIDEE differences often exceed $20 \mathrm{mg} \mathrm{m}^{-2}$ month $^{-1}$. Both inventories show a decrease in emissions in the tropics and in the Northern Hemisphere in late 1991 and early 1992. The strength and the duration of the decrease differs between the two inventories. In the equatorial region, ORCHIDEE gives decreases that often surpass $20 \mathrm{mg} \mathrm{m}^{-2}$ month $^{-1}$ from 1992 to 1995 . LPJ reports decreased emissions in the equatorial region in the second half of 1991 and the first half of 1992. This period is followed by alternating short periods of increased and decreased emissions near the Equator until 1995. Both inventories give some increases in emissions in the subtropics throughout the period and a strong increase in emissions throughout the tropics in the second half of 1995 and beginning of 1996. In the northern mid-latitudes and high latitudes, decreases of 2 to $5 \mathrm{mg} \mathrm{m}^{-2}$ month $^{-1}$ are maintained from the second half of 1991 to mid-1993 in LPJ. In ORCHIDEE, $\mathrm{CH}_{4}$ emissions decrease by up to $20 \mathrm{mg} \mathrm{m}^{-2}$ month $^{-1}$ in the first half of 1992, but are compensated by increases of similar magnitude in the second half of 1992. Increased emissions are reported by ORCHIDEE in this region every summer from 1993 to 1995.

Variations in emissions other than wetlands also cause significant changes in the $\mathrm{CH}_{4}$ budget. The $\mathrm{CH}_{4}$ emissions are affected by variations in biomass burning and anthropogenic activity (Fig. 2g). Anthropogenic emissions in the northern mid-latitudes show a gradual decrease of up to $20 \mathrm{mg} \mathrm{m}^{-2}$ month $^{-1}$ from 1990 to 1996 . This decrease is compensated by an increase in anthropogenic emissions in the tropical region, with values reaching 5 to $10 \mathrm{mg} \mathrm{m}^{-2}$ month $^{-1}$ between 15 and $30^{\circ} \mathrm{N}$. Enhanced biomass burning emissions are also found close to the Equator in the autumn of the years 1991, 1992, and 1994.

The modelled growth rate variations caused by the changes in $\mathrm{CH}_{4}$ sources and sinks described above are depicted in Fig. 3. A 12-month running mean was applied to all the growth rate variations, to remove seasonal effects. The black line shows the cumulative effect of these processes on the $\mathrm{CH}_{4}$ growth rate, representing the combined effect of all considered drivers of variability on the global $\mathrm{CH}_{4}$ growth rate, which we will refer to as the "explained" $\mathrm{CH}_{4}$ growth rate. We assume here additivity between the changes in $\mathrm{CH}_{4}$ growth rate caused by the different drivers. The effect of nonlinearities is discussed in Appendix B. Figure $3 \mathrm{a}$ and $\mathrm{b}$ show the two cases in which the ORCHIDEE and LPJ inventory, respectively, are used to represent the effect of IAV on wetland $\mathrm{CH}_{4}$ emissions. In early 1991 the $\mathrm{CH}_{4}$ growth rate remains within $2 \mathrm{ppb} \mathrm{yr}^{-1}$ of that in 1990 . Values of more than $10 \mathrm{ppbyr}^{-1}$ are found in 1990-1991 (see Fig. A1) due to relatively high emissions from all source categories of $\mathrm{CH}_{4}$. The relatively large ozone column values in these years, together with large emissions of CO and NMVOC, lead to a reduced $\mathrm{CH}_{4}$ sink in 1990 and 1991. During 1991 the explained $\mathrm{CH}_{4}$ growth rate remains stable or shows a moderate increase depending on whether the ORCHIDEE or, respectively, LPJ inventory is used. The explained $\mathrm{CH}_{4}$ growth rate decreases afterwards by $9-10 \mathrm{ppb} \mathrm{yr}^{-1}$ in both cases, partly due to a decrease in wetland emissions. While $\mathrm{CH}_{4}$ emissions from wetlands gradually recover, a combination of other processes leads to a continued decrease in $\mathrm{CH}_{4}$ growth rate until 1993. The processes contributing to the decrease in the explained $\mathrm{CH}_{4}$ growth rate in the second half of 1992 and early 1993 are stratospheric $\mathrm{O}_{3}$ depletion, a recovery of stratospheric aerosols towards background levels, and changes in emissions other than $\mathrm{CH}_{4}$ emissions from wetlands. The former effect includes a decrease in $\mathrm{CH}_{4}$ emissions from biomass burning of 4-5 $\mathrm{Tg} \mathrm{yr}^{-1}$ between 1992 and 1993, and a $2 \mathrm{Tg} \mathrm{yr}^{-1}$ decrease in anthropogenic emissions. This would lead to a combined decrease of $6-7 \mathrm{Tg} \mathrm{yr}^{-1}$, or $2 \mathrm{ppb} \mathrm{yr}^{-1}$. A decrease in isoprene emissions of $60 \mathrm{Tg} \mathrm{yr}^{-1}$ and a decrease of $50 \mathrm{Tg} \mathrm{yr}^{-1}$ in $\mathrm{CO}$ emissions also occur over this period. They cause an increase in the $\mathrm{CH}_{4}$ removal and lead to a decrease of $6 \mathrm{ppb} \mathrm{yr}^{-1}$ in FixEmis1 compared to NoPinS1. The overall effect remains stable at -6 to $-7 \mathrm{ppb} \mathrm{yr}^{-1}$ from mid 1993 to spring 1994.

Although the evolution of the explained $\mathrm{CH}_{4}$ growth rate shows similar features when using the two wetland emission inventories, some significant differences occur. First, the more pronounced decrease in $\mathrm{CH}_{4}$ emissions in ORCHIDEE in 1991 compensates the concurrent decrease in the $\mathrm{CH}_{4}$ sink due to stratospheric aerosols and meteorological changes, leading to a stable $\mathrm{CH}_{4}$ growth rate during 1991. The decrease in LPJ emissions in 1991 is much smaller, resulting in a $3.5 \mathrm{ppb} \mathrm{yr}^{-1}$ increase in $\mathrm{CH}_{4}$ growth rate in the second half of 1991. The decrease in the explained $\mathrm{CH}_{4}$ growth rate that follows in 1992 starts about half a year later when using LPJ emissions than when using ORCHIDEE. The $8 \mathrm{ppb} \mathrm{yr}^{-1}$ decrease in the growth rate obtained due to ORCHIDEE in late 1991 and early 1992 causes an earlier decrease in the overall growth rate. The minimum $\mathrm{CH}_{4}$ growth rate also occurs about 3 months earlier with ORCHIDEE than with LPJ. Finally, an additional $3 \mathrm{ppb} \mathrm{yr}^{-1}$ growth rate decrease occurs during 1994 with ORCHIDEE, while LPJ gives a stable $\mathrm{CH}_{4}$ growth rate between mid-1993 and mid-1995. 

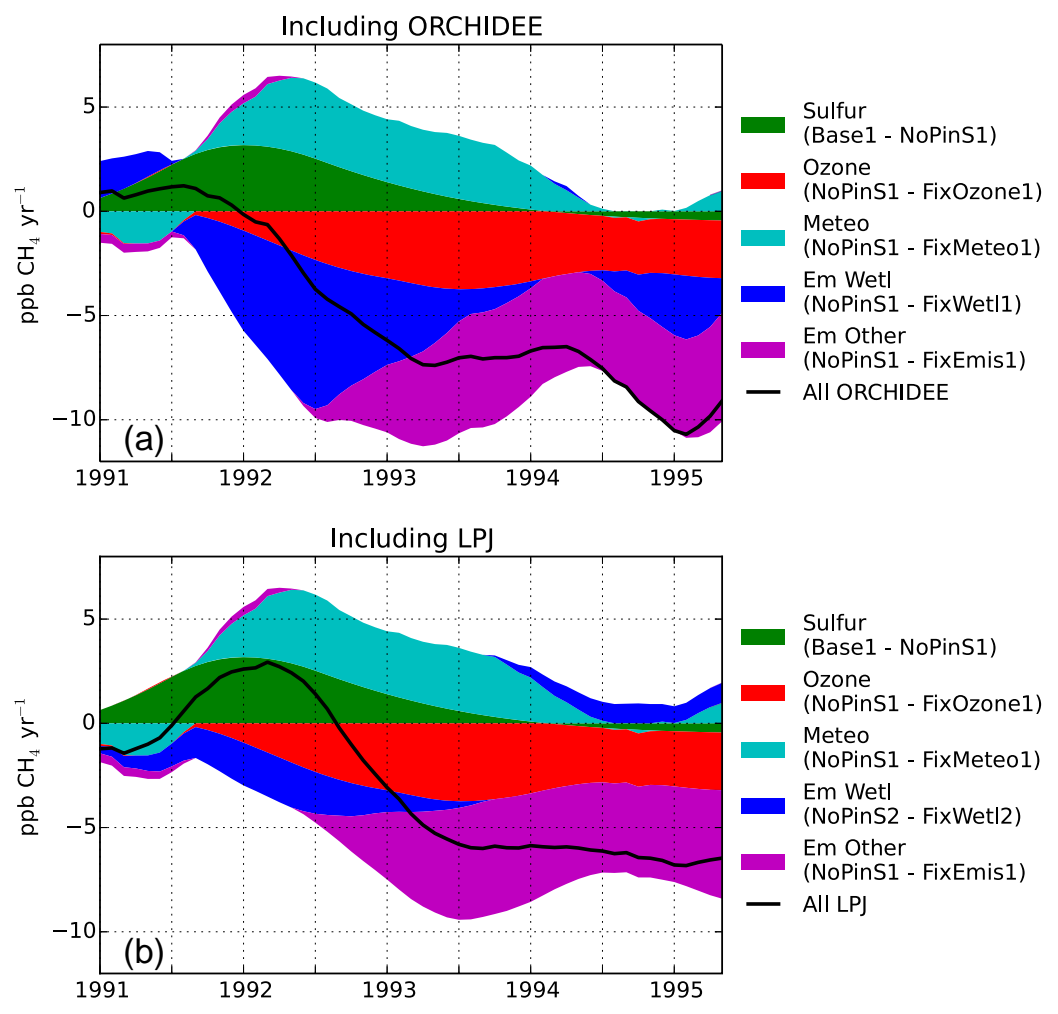

Figure 3. Global $\mathrm{CH}_{4}$ growth rate variations with respect to the year 1990 induced by the different drivers, using (a) ORCHIDEE and (b) LPJ to represent variability in $\mathrm{CH}_{4}$ emissions from wetlands. Simulations from Set I are used in both plots to infer the effect of stratospheric sulfur, stratospheric ozone, meteorology and emissions other than wetlands. Simulations from Set II are used only to infer the effect of LPJ emission variability. The overall variability ("All”) is calculated as the sum of the individual variations.

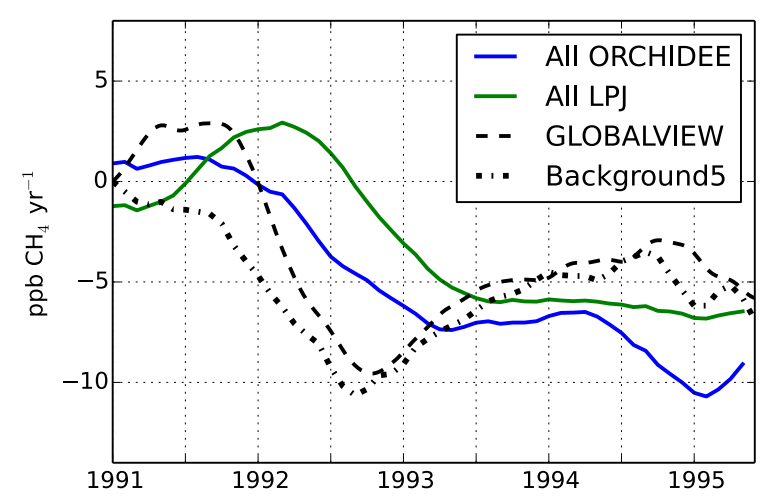

Figure 4. The explained $\mathrm{CH}_{4}$ growth rate variability in the model using two wetland $\mathrm{CH}_{4}$ emission inventories, and global deseasonalised $\mathrm{CH}_{4}$ growth rate differences with respect to 1990 from the GLOBALVIEW observations, and from observations at five background stations.

Our explained $\mathrm{CH}_{4}$ growth rates are compared to observations in Fig. 4. Two estimates for the observed global mean growth rate are shown. The first estimate is calculated from the NOAA GLOBALVIEW-CH4 (2009) marine boundary layer zonal mean $\mathrm{CH}_{4}$ concentrations. The second estimate,
"Background5", is taken from the $\mathrm{CH}_{4}$ background data used for nudging the model, based on measurements from five stations (see Sect. 2.2). The other $\mathrm{CH}_{4}$ growth rate curves in Fig. 4 are the same as the black lines in Fig. 3, representing the explained growth rate differences with respect to 1990. In order to obtain the variability with respect to the year 1990 from the observations, the $1990 \mathrm{CH}_{4}$ growth rates have been subtracted from both observation time series (see absolute growth rate values in Fig. A1). A running mean of 12 months was further applied to remove seasonal effects. The explained $\mathrm{CH}_{4}$ growth rate variability shows differences of -1.0 to $2.5 \mathrm{ppb} \mathrm{yr}^{-1}$ in 1991 with respect to 1990 , which falls in between the two observational estimates of $3 \mathrm{ppb} \mathrm{yr}^{-1}$ for GLOBALVIEW-CH4, and $-1.5 \mathrm{ppb} \mathrm{yr}^{-1}$ for Background5. The model gives an increase of $3.5 \mathrm{ppb} \mathrm{yr}^{-1}$ over the course of 1991 when using LPJ, while using ORCHIDEE, we find a decrease of $1 \mathrm{ppb} \mathrm{yr}^{-1}$. The observations from GLOBALVIEW show an increase in the $\mathrm{CH}_{4}$ growth rate in the first half of 1991 and a decrease in the second half, while the Background5 growth rate decreases throughout the year 1991. A continued decrease in the $\mathrm{CH}_{4}$ growth rate is found in observations in 1992, reaching $-10 \mathrm{ppb} \mathrm{yr}^{-1}$ in autumn 1992. The explained growth rate also decreases compared to 1990 when using ORCHIDEE emissions, reach- 


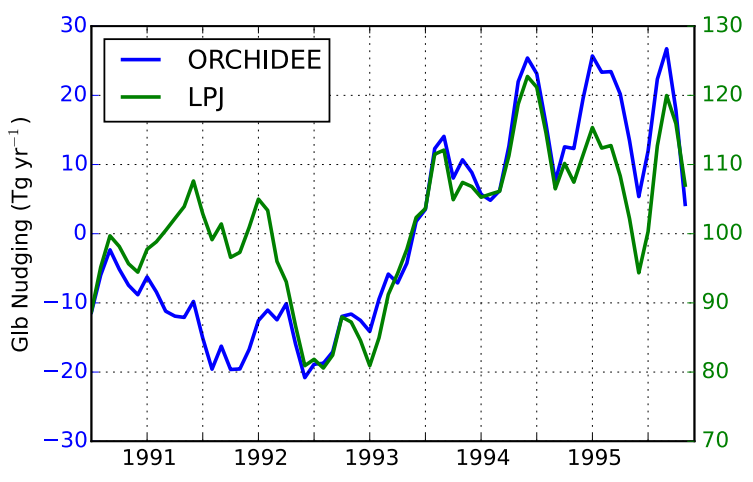

Figure 5. Global deseasonalised $\mathrm{CH}_{4}$ nudging term for the Base1 (left $y$ axis) and Base2 (right $y$ axis) simulations, using $\mathrm{CH}_{4}$ wetland emissions from ORCHIDEE and LPJ, respectively.

ing $-8 \mathrm{ppb} \mathrm{yr}^{-1}$ about half a year later than the observations. With LPJ emissions, the decrease in the $\mathrm{CH}_{4}$ growth rate occurs between spring 1992 and summer 1993, reaching $-6 \mathrm{ppbyr}^{-1}$. The observations show a further recovery at the end of 1992 and the first half of 1993 to $-5 \mathrm{ppb} \mathrm{yr}^{-1}$, remaining relatively constant for the rest of the period. The recovery is not captured in the model, irrespective of the wetland emissions used. The explained growth rate in the model remains stable in the second half of 1993 and first half of 1994 and, in the case of ORCHIDEE emissions, decreases again in the second half of 1994.

\subsection{Unexplained $\mathrm{CH}_{4}$ variability}

As explained in Sect. 2.2, $\mathrm{CH}_{4}$ observations are used in a first step to quantify the mismatch between the model and observations. This nudging amount is analysed further to better understand the possible reasons for this mismatch.

The global deseasonalised nudging amounts for Base 1 and Base2 are shown in Fig. 5. Due to the difference of about $100 \mathrm{Tg} \mathrm{yr}^{-1}$ in the global emissions from the two wetland inventories, the global nudging amount also shows an offset of similar magnitude. The global nudging over the period 1990 to 1995 is close to 0 with ORCHIDEE, and about $100 \mathrm{Tg} \mathrm{yr}^{-1}$ with LPJ. However, there is quite some variability for both simulations within a range of about $50 \mathrm{Tg} \mathrm{yr}^{-1}$. In the first period of the simulation, the nudging term for the ORCHIDEE simulations varies between 0 and $-20 \mathrm{Tg} \mathrm{vr}^{-1}$, and between 75 and $105 \mathrm{Tg} \mathrm{yr}^{-1}$ for LPJ. The nudging increases by $25-30 \mathrm{Tg} \mathrm{yr}^{-1}$ during the first half of 1993 for both Base1 and Base2 because the increase in the observed $\mathrm{CH}_{4}$ growth rate in this period is not reproduced by the explained growth rate. Between the second half of 1993 and the end of 1995, the nudging term for the two simulations shows similar variations, between 5 and $30 \mathrm{Tg} \mathrm{yr}^{-1}$ for ORCHIDEE, and between 100 and $125 \mathrm{Tg} \mathrm{yr}^{-1}$ for LPJ.

To better quantify the nudging term, the zonal mean nudging amounts for the two simulations as a function of time are given in Fig. $6 \mathrm{c}$ and d. The zonal mean emission and sink strengths for the Base1 simulation are also shown for comparison in Fig. 6a and b. In both simulations, nudging is predominantly needed in the Northern Hemisphere, where most $\mathrm{CH}_{4}$ is emitted. This suggests that the uncertainties related to the $\mathrm{CH}_{4}$ sources dominate the ones related to the sink or to transport, which occur in both hemispheres. Positive nudging is needed in the tropics in both hemispheres with a maximum during autumn, and following the position of the inter-tropical convergence zone (ITCZ). This suggests either missing emissions from tropical wetlands or biomass burning, or an overestimated strength of the tropical OH sink. In the northern mid-latitudes, the model overestimates $\mathrm{CH}_{4}$ concentrations in the winter, and underestimates concentrations in the summer. This suggests a missing seasonality in one of the $\mathrm{CH}_{4}$ budget terms. Positive nudging amounts at northern high latitudes are needed throughout the two simulations, except for Base1 during autumn, where negative nudging is required. These might be related to underestimated anthropogenic emissions, as well as to errors in transport or vertical mixing, since both natural emissions and the $\mathrm{CH}_{4}$ sink are almost negligible at high latitudes during winter.

In Fig. 6e and $\mathrm{f}$ the nudging for the year 1990 was subtracted from the whole time series, and a 12-month running mean was applied. These plots thus highlight the potential missing IAV in the model compared to observations. For both simulations we find a missing decrease in the $\mathrm{CH}_{4}$ burden in the northern tropics during 1991 to 1993 . This points to either a missing decrease in both wetland emission inventories in this region or to potential uncertainties in tropical biomass burning. At northern mid-latitudes the $\mathrm{CH}_{4}$ emissions are dominated by anthropogenic emissions; therefore, the missing $\mathrm{CH}_{4}$ increase revealed in this region suggests that the decrease in anthropogenic emissions over Europe, North America and the FSU in this time period might be overestimated. When using ORCHIDEE emissions we find an additional missing increase in the southern tropics from 1992 onwards, in particular in 1993 and 1995.

\section{Discussion}

We have quantified for the first time all known major drivers of $\mathrm{CH}_{4}$ variability in the early 1990s in a global chemistry and transport model. Previous attempts to explain the $\mathrm{CH}_{4}$ evolution in this period were the inverse modelling studies of W04 and B06. The sensitivity of the $\mathrm{CH}_{4}$ growth rate to most of the drivers presented here was also investigated in our previous study (Bândă et al., 2013), using a column chemistry model. Other bottom-up studies have focused on only one of the potential causes of $\mathrm{CH}_{4}$ variability during the postPinatubo period. In the following sections we compare our results to previous top-down and bottom-up studies, and discuss potential sources of uncertainty in our results. 

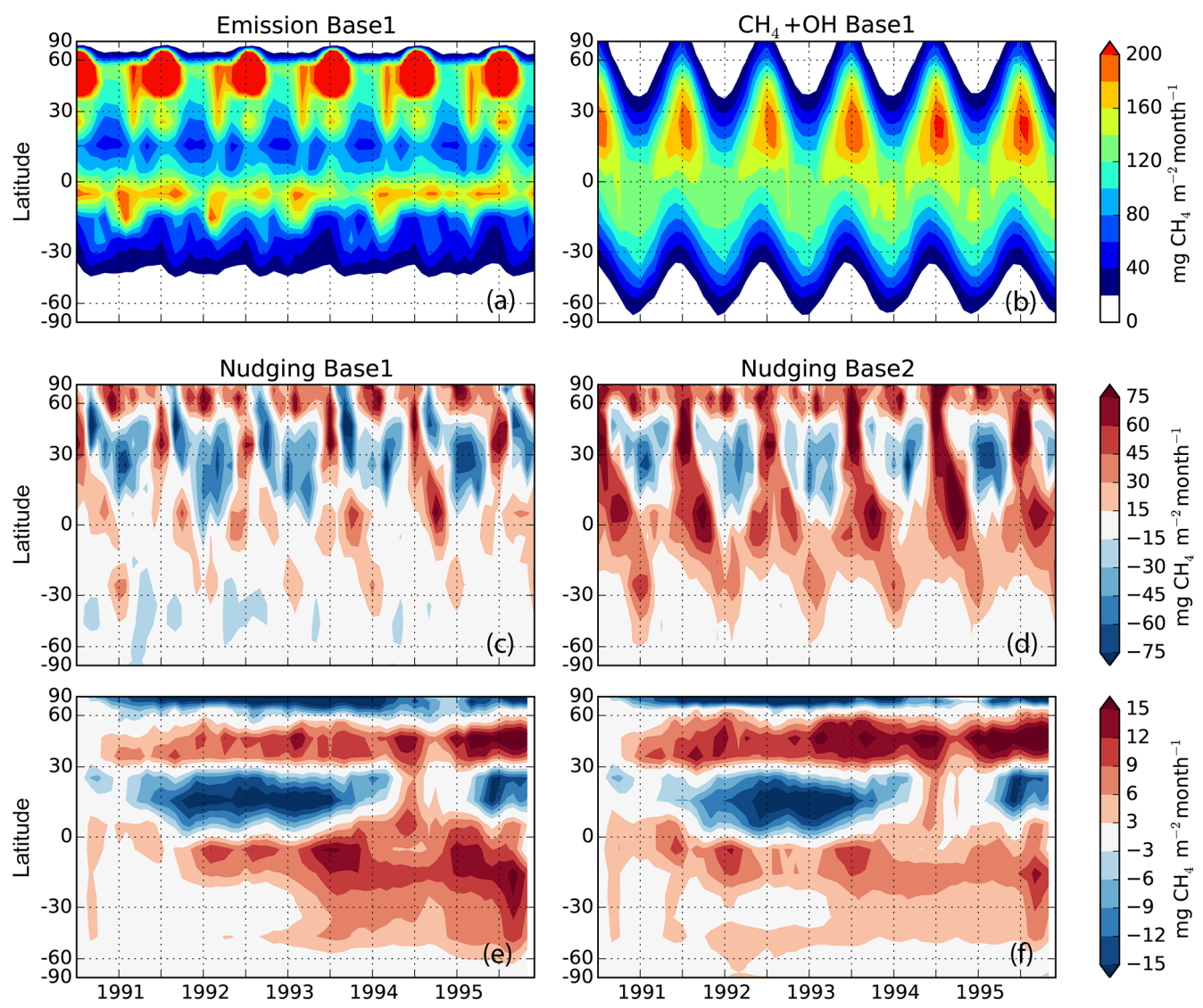

Figure 6. Zonal mean $\mathrm{CH}_{4}$ (a) emission and (b) sink by reaction with $\mathrm{OH}$ in the Base1 simulation, zonal mean $\mathrm{CH}_{4}$ nudging term when using $\mathrm{CH}_{4}$ wetland emissions from (c) ORCHIDEE (Base1 simulation) and (d) LPJ (Base2 simulation), and (e) and (f) the deseasonalised nudging anomaly compared to 1990 .

\subsection{Comparison to inverse modelling studies}

The $\mathrm{CH}_{4}$ inverse modelling studies of W04 and B06 included the post-Pinatubo period. The $\mathrm{OH}$ fields used were derived by different methods. W04 used parameterised $\mathrm{OH}$ fields based on chemistry model results. Changes in meteorology, $\mathrm{O}_{3}$ column, concentrations of $\mathrm{CO}$ and $\mathrm{NMVOC}$ were included in their parameterisation. However, stratospheric aerosols from the Pinatubo eruption were not included. The $\mathrm{OH}$ fields in B06 were determined from an inversion of methyl chloroform observations, and might be affected by uncertainties in emissions of methyl chloroform.

With regard to the either applied or inferred $\mathrm{OH}$ sink variations, the inversion studies for this time period are only partly in line with our simulated variations in the $\mathrm{OH}$ sink, including the combined effect of stratospheric aerosols, stratospheric $\mathrm{O}_{3}$ depletion and tropospheric emissions of $\mathrm{CO}$ and NMVOCs. We will now discuss the comparison between our results with these earlier studies for the different time periods: (i) the sharp decrease in the $\mathrm{CH}_{4}$ growth rate in the second half of 1991 and throughout 1992, (ii) the subsequent increase in the $\mathrm{CH}_{4}$ growth rate in 1993, (iii) the moderate growth rates over the years 1994 and 1995, and (iv) the decrease in the $\mathrm{CH}_{4}$ growth rate over the period 1990 to 1995.

1991-1992 W04 inferred a slight decrease in the OH sink of $\mathrm{CH}_{4}$ in 1991 compared to 1990, and an increase of about $10 \mathrm{Tg} \mathrm{yr}^{-1}$ in 1992. In B06, a decrease of about $25 \mathrm{Tg} \mathrm{yr}^{-1}$ in the $\mathrm{OH}$ sink was found during 1990 to 1992. In our study we find smaller OH variations than both studies, with a decrease in the $\mathrm{OH}$ sink of $\mathrm{CH}_{4}$ of about $5 \mathrm{Tg} \mathrm{yr}^{-1}$ in 1992 compared to 1990 and 1991. This reduction in $\mathrm{OH}$ is due to sulfate aerosols and atmospheric cooling, compensated by the $\mathrm{OH}$ increase caused by ozone depletion (see Table 1, Fig. 3).

Based on their assumed $\mathrm{OH}$ concentrations, W04 obtained a $20-25 \mathrm{Tg}$ decrease in wetland emissions in 1992 compared to 1991 and 1990. To explain the decrease in the $\mathrm{CH}_{4}$ growth rate in 1992, B06 found a $35-40 \mathrm{Tg} \mathrm{yr}^{-1}$ decrease in wetland emissions in the first half of 1992. To compensate for their simultaneous decrease in $\mathrm{OH}$ sink, they found $5-10 \mathrm{Tg}$ lower biomass burning emissions in 1992 than 1991 and 1993, and a $20 \mathrm{Tg}$ decrease in anthropogenic emissions, which is 
sustained for the rest of the 1990s. With ORCHIDEE we applied a $25 \mathrm{Tg} \mathrm{yr}^{-1}$ emission decrease in 1992. Our nudging suggests that this decrease could reach $29 \mathrm{Tg} \mathrm{yr}^{-1}$, which is similar in magnitude to the other studies.

1993 The observed $\mathrm{CH}_{4}$ growth rate partially recovers during 1993 from the strong decrease in the year 1992. In our study we capture the decrease in $\mathrm{CH}_{4}$ growth rate in 1993 rather than 1992 due to a $22 \mathrm{Tg}$ increase in the $\mathrm{OH}$ sink of $\mathrm{CH}_{4}$ because of reduced ozone columns, biomass burning emissions and a recovery of sulfate aerosols. A partial recovery in wetland emissions is found in both inventories. This recovery might be underestimated, since an increase in the nudging term is needed to explain the observed growth rate. Both W04 and B06 found increases in the $\mathrm{CH}_{4}$ sink of about $10 \mathrm{Tg} \mathrm{yr}^{-1}$ during 1993 . Similarly to our study, W06 simulate a continued decrease in $\mathrm{CH}_{4}$ growth rate rather than a recovery. In B06, increases in wetland and biomass burning emissions in 1993 are found to overwhelm the increase in the $\mathrm{CH}_{4}$ sink, leading to an increase in the $\mathrm{CH}_{4}$ growth rate.

1994-1995 The $\mathrm{OH}$ sink of $\mathrm{CH}_{4}$ showed variations of 3 to $5 \mathrm{Tg} \mathrm{yr}^{-1}$ in W06 in the years 1993 to 1995 , while an increase of about $15 \mathrm{Tg} \mathrm{yr}^{-1}$ in the years 1993 to 1995 was obtained in B06. In agreement with B06, we find a $12 \mathrm{Tg} \mathrm{yr}^{-1}$ increase in the $\mathrm{OH}$ sink of $\mathrm{CH}_{4}$ between 1993 and 1995 due to the recovery of the anomaly in temperature, water vapour and stratospheric aerosols caused by the eruption.

Similar to the study of W06, we find that the decrease in the $\mathrm{CH}_{4}$ growth rate over the period 1990 to 1995 can be entirely explained by an increase in the $\mathrm{OH}$ sink of $\mathrm{CH}_{4}$, rather than by changes in emissions. In B06, however, this decrease in $\mathrm{CH}_{4}$ growth rate is explained by a decrease in anthropogenic emissions.

The more recent study of Pison et al. (2013) extended the study of B06 by using both methyl chloroform and $\mathrm{CH}_{4}$ observations to constrain $\mathrm{OH}$ concentrations in their INVARR inversion. Smaller OH variability is found in this case compared to B06, and their derived global emission changes are more in line with W04 and with the emissions applied in our first simulation set.

The $1.6 \%$ IAV we find for the $\mathrm{CH}_{4}$ loss by reaction with $\mathrm{OH}$ supports the conclusion of Montzka et al. (2011) that $\mathrm{OH}$ concentrations are buffered against atmospheric perturbations, having an IAV of about $2 \%$. The large $\mathrm{OH}$ inter-annual variations, often exceeding $10 \%$, previously found for the 1990s using methyl chloroform observations are not reproduced in our chemistry-transport simulations (Prinn et al., 2005; Bousquet et al., 2005).

\subsection{Comparison to previous bottom-up studies}

In Bândă et al. (2013), we analysed the $\mathrm{CH}_{4}$ growth rate variability after the Pinatubo eruption using a column chemistry model. The timing of the minimum $\mathrm{CH}_{4}$ growth rate reported in that study is similar to the one found in this threedimensional study, implying that the delay compared to observations is a result of uncertainties in model input rather than model set-up. However, some differences between the two studies occur in the magnitude and contribution of the different processes to the $\mathrm{CH}_{4}$ growth rate decrease in 1991 to 1993. In Bândă et al. (2013), the overall explained growth rate decrease was found to be $12 \mathrm{ppb} \mathrm{yr}^{-1}$, while here we find only 8 to $10 \mathrm{ppbyr}^{-1}$. A $5 \mathrm{ppb} \mathrm{yr}^{-1}$ decrease was found due to $\mathrm{CH}_{4}, \mathrm{NO}_{X}$ and $\mathrm{CO}$ anthropogenic emission changes. This is similar to the decrease of $6 \mathrm{ppb} \mathrm{yr}^{-1}$ due to changes in non-wetland emissions obtained in this study. However, our current estimate also includes variations of emissions from biomass burning, natural emissions of $\mathrm{CO}$ and NMVOC. The sulfate aerosol and $\mathrm{O}_{3}$ column effects also differ by 2 to $3 \mathrm{ppb} \mathrm{yr}^{-1}$ from the estimates presented in Bândă et al. (2013), probably because the regional distribution of these effects could not be taken into account in the simplified column model approach. Furthermore, our previous study showed that $\mathrm{CH}_{4}$ concentrations are affected for a long time period after a perturbation is applied due to the $\mathrm{CH}_{4}$ lifetime of about 10 years. This delayed effect can be seen here for stratospheric sulfur, where a small negative difference in the $\mathrm{CH}_{4}$ growth rate is found towards the end of the simulation period (Fig. 3). The delayed effect that a perturbation in a driver of $\mathrm{CH}_{4}$ variability has on the $\mathrm{CH}_{4}$ growth rate also occurs in our other simulations. However, it is in general overwhelmed by the instantaneous effect of variability in the $\mathrm{CH}_{4}$ driver.

Other studies have focused on only one of the drivers of $\mathrm{CH}_{4}$ variability after the Pinatubo eruption. Bekki and Pyle (1994) found a decrease in the $\mathrm{CH}_{4}$ growth rate of $7 \mathrm{ppb} \mathrm{yr}^{-1}$ globally due to stratospheric $\mathrm{O}_{3}$ using a two-dimensional model between spring 1991 and autumn 1992. Here we obtain a comparable estimate of $5 \mathrm{ppbyr}^{-1}$ decrease over the period 1991 to autumn 1993 due to the pronounced stratospheric $\mathrm{O}_{3}$ depletion in the tropics and northern mid-latitudes in 1993.

Using a two-dimensional chemistry and transport model, Bekki and Law (1997) investigated the effect of temperature on both chemistry and wetland emissions in 1991-1992. They found that the temperature decrease after Pinatubo led to a $4 \mathrm{ppb} \mathrm{yr}^{-1}$ increase in the global $\mathrm{CH}_{4}$ growth rate between mid-1991 and mid-1992, similar to our meteorological effect of $5 \mathrm{ppb} \mathrm{yr}^{-1}$. By applying a $Q_{10}=2$ temperature sensitivity of $\mathrm{CH}_{4}$ emissions (Dunfield et al., 1993), they found that $\mathrm{CH}_{4}$ emissions from wetlands would decrease the $\mathrm{CH}_{4}$ growth rate by $2 \mathrm{ppb} \mathrm{yr}^{-1}$ in the same period. This is similar to our result using LPJ wetland emissions. The ORCHIDEE inventory gives a much larger decrease in the $\mathrm{CH}_{4}$ growth 
rate of $9 \mathrm{ppb} \mathrm{yr}^{-1}$, which overwhelms the meteorological effect on the $\mathrm{CH}_{4}$ sink. This shows that the climate sensitivity of wetland emissions is larger in ORCHIDEE, where changes in wetland extent are taken into account.

Stratospheric aerosols were found to enhance the BrewerDobson circulation after the Pinatubo eruption (Aquila et al., 2013). This change in the dynamics of the atmosphere might also affect $\mathrm{CH}_{4}$ concentrations. Schauffler and Daniel (1994) hypothesised that increased exchange between the stratosphere and troposphere might be responsible for the decrease in $\mathrm{CH}_{4}$ growth rate observed in 1992. By performing an additional simulation where only temperature and humidity were fixed to 1990 values, we found that the meteorological effect is dominated by the effect of these two variables (results not shown). The global impact of changes in ERA-Interim wind fields is marginal. The wind fields in ERA-Interim have some uncertainty for the first weeks after the eruption related to the fact that Pinatubo aerosols are not explicitly accounted for. However, the longer-term effect on temperature and the corresponding dynamical effect are included in ERA-Interim through the assimilation of satellite radiances.

Dlugokencky et al. (1994) and Law and Nisbet (1996) hypothesised that the emission decline in the FSU could have had a significant contribution to the decrease in $\mathrm{CH}_{4}$ concentrations during 1992, because the decrease is primarily found in the Northern Hemisphere. However, our results indicate a missing $\mathrm{CH}_{4}$ burden decrease in 1992 which originates in the northern tropics (Fig. 6). Furthermore, a missing increase in $\mathrm{CH}_{4}$ concentrations is found in the Northern Hemisphere extratropics, pointing to a potential missing source in this region rather than reduced emissions due to gas leak fixes. Furthermore, the overall decrease in growth rate between 1990 and 1996 is captured by our model, and can be attributed to stratospheric $\mathrm{O}_{3}$ decrease over this period, and decreases in biomass burning and biogenic emissions of NMVOC and $\mathrm{CO}$. We acknowledge, however, that the nudging procedure used here introduces some uncertainty in providing the location of missing emissions. The procedure attributes the source-sink mismatch at the dateline to sources or sinks in the same $10^{\circ}$ latitude band. Potential sub-monthly transport of emissions from other latitudes is not taken into account. To further constrain the sources of model-measurement mismatch, an inverse modelling study should be performed to estimate the variability of the $\mathrm{CH}_{4}$ sources using modelled $\mathrm{OH}$ variability.

\subsection{Potential sources of uncertainty}

In this study all known major drivers of $\mathrm{CH}_{4}$ variability have been included. We estimate that potential missing processes had a minor effect on $\mathrm{CH}_{4}$ concentrations, and would therefore not significantly affect our results. Such processes are the radiative effects of ash and water vapour injected into the stratosphere by the eruption, and the effect of sulfur deposition on $\mathrm{CH}_{4}$ emissions from wetlands. Ash particles emitted by the eruption have a short lifetime of a few days (Guo et al., 2004; Niemeier et al., 2009), and were found to have a negligible effect on global radiation. Changes in water vapour are included through ERA-Interim reanalysis, and might contain some uncertainties (Dessler et al., 2014). Sulfur deposition has also been proposed to affect $\mathrm{CH}_{4}$ emissions from wetlands (Gauci and Chapman, 2006). This effect is not included in our input data. In Bândă et al. (2013) we made a rough estimate of this effect, and found it to be of the order of $1 \mathrm{Tg} \mathrm{CH}_{4} \mathrm{yr}^{-1}$ for the Pinatubo eruption.

The zonal mean nudging term in our model points to either underestimated emissions or overestimated sinks in the tropics and during summer at mid-latitudes. An overestimated source is identified at mid-latitude during winter. Uncertainties in the $\mathrm{OH}$ sink of $\mathrm{CH}_{4}$ might relate to uncertainties in the chemistry. $\mathrm{CO}$ concentrations in TM5 are underestimated at the northern mid-latitudes (Huijnen et al., 2010; van Noije et al., 2014), which might lead to overestimated $\mathrm{OH}$ concentrations in this region. An overestimate in $\mathrm{OH}$ concentrations at northern mid-latitudes and an overestimated northsouth gradient in global chemistry models is also found from methyl chloroform observations in Patra et al. (2014). In the tropics, $\mathrm{OH}$ uncertainties might arise due to NMVOC chemistry, and are discussed in more detail below. Other uncertainties in tropical $\mathrm{OH}$ might relate to $\mathrm{NO}_{X}$ and $\mathrm{CO}$ emission factors from biomass burning. $\mathrm{CO}$ decreases $\mathrm{OH}$ concentrations, while $\mathrm{NO}_{X}$ increases $\mathrm{OH}$ recycling; therefore, the overall effect of biomass burning emissions on $\mathrm{OH}$ is strongly dependent on the emission factors of these species, which are uncertain in the tropical region in the early 1990s (Schultz et al., 2008).

Our results show that the decrease in $\mathrm{CH}_{4}$ growth rate observed in 1992 is reasonably well explained by the processes considered here. However, the exact timing of the minimum growth rate is captured 6 to 9 months later than in the observations. Since missing processes are estimated to have a small impact on $\mathrm{CH}_{4}$ variability in the early 1990 s, the mismatch between modelled and measured $\mathrm{CH}_{4}$ concentrations can only be related to uncertainties in either input data or modelled $\mathrm{CH}_{4}$ processes. Measurement uncertainty might also contribute to the mismatch. The differences given by the two measurement-based estimates of the global $\mathrm{CH}_{4}$ growth rate in Fig. 4 show that uncertainties can be of the order of $2-3 \mathrm{ppb} \mathrm{yr}^{-1}$. Our input data and chemical processes related to aerosols, $\mathrm{O}_{3}$ and meteorological effects are fairly well studied and understood. The uncertainty related to these processes is of the order of 10-20\%, and cannot explain the different timing of the decrease in $\mathrm{CH}_{4}$ growth rate between the model and observations.

Larger uncertainties are related to the $\mathrm{CH}_{4}$ emissions. The differences between the $\mathrm{CH}_{4}$ emissions from the ORCHIDEE and LPJ inventories, both in terms of magnitude and IAV (Table 1), show that there are still many unknowns in the processes governing emissions from wetlands. One of the most important differences between the two mod- 
els is the fact that ORCHIDEE simulates changes in wetland extent, while LPJ uses fixed wetland extent. This might be the cause of the larger IAV in ORCHIDEE, and of the higher climate sensitivity. Large differences in the response of ten wetland emission models to a temperature perturbation were also found in the WETCHIMP model intercomparison project, showing that a better understanding of wetland processes is needed (Melton et al., 2013).

Biomass burning emission uncertainties could also contribute to the mismatch between model and observations. However, given the IAV in biomass burning emissions in both the RETRO and the more recent GFED emission inventory of about $3 \mathrm{TgCH}_{4} \mathrm{yr}^{-1}$, it is unlikely that uncertainties in biomass burning $\mathrm{CH}_{4}$ emissions could be the sole reason for the mismatch. As explained above, it is also unlikely that anthropogenic emission changes due to gas leak fixes within the FSU contributed to the mismatch.

We find a significant impact of CO and NMVOC emission changes on the $\mathrm{CH}_{4}$ removal by $\mathrm{OH}$. Some uncertainty is associated with NMVOC emission changes and their effect on $\mathrm{CH}_{4}$ chemistry in the period after Pinatubo. Natural emissions of isoprene respond to both changes in climate and in solar radiation (Telford et al., 2010; Wilton et al., 2011). A decrease in surface temperatures would lead to a reduction in isoprene emissions. Concerning the effects of radiation, the increase in diffuse radiation after the eruption, leading to deeper penetration into canopies, has been shown to have overwhelmed the effect of decreased direct radiation in terms of plant growth (Mercado et al., 2009). Therefore the increase in diffuse radiation would have increased isoprene emissions. However, in this study only the effect of climate change and the effect of decrease in total shortwave radiation after the eruption are included through the MEGAN inventory. The isoprene emissions in MEGAN show a decline of $50 \mathrm{Tg} \mathrm{yr}^{-1}$ globally during 1992, likely due to the decrease in surface temperature and global shortwave radiation. The $\mathrm{CH}_{4}$ growth rate decreases by about $4 \mathrm{ppb} \mathrm{yr}^{-1}$, or $11 \mathrm{Tg} \mathrm{yr}^{-1}$ due to changes in emissions of other species than $\mathrm{CH}_{4}$ including isoprene. These changes are of similar magnitude as found in Telford et al. (2010), where a $40 \mathrm{Tg}$ decrease in isoprene emissions between 1990 and 1992 resulted in a 5 Tg increase in $\mathrm{CH}_{4}$ removal by $\mathrm{OH}$. The estimated effect of NMVOC emissions on $\mathrm{CH}_{4}$ concentrations has several sources of uncertainty. Firstly, including the effect of Pinatubo on diffuse radiation might have led to increased NMVOC emissions in 1991-1992, and an even stronger decrease in 1993, when the aerosols were removed from the atmosphere. Secondly, recent studies have shown that the sensitivity of $\mathrm{OH}$ concentrations to NMVOC is smaller than previously thought (Stone et al., 2011; Rohrer et al., 2014). The CBM4 chemistry scheme used here does not include an updated isoprene chemistry mechanism, and might exhibit too high an $\mathrm{OH}$ sensitivity to isoprene. Telford et al. (2010) used a chemistry scheme that includes the Mainz isoprene mechanism, a parameterisation based on the Master Chemical Mechanism
(MCM), which was also shown to misrepresent $\mathrm{OH}$ recycling in VOC-rich environments (Pöschl et al., 2000; Stone et al., 2011). Nevertheless, it is important to take NMVOC emission changes into account for evaluating $\mathrm{CH}_{4}$ variability. Due to the potentially overestimated $\mathrm{OH}$ sensitivity, our calculated effect on $\mathrm{CH}_{4}$ can be seen as an upper estimate.

The latitudinal nudging term needed to correct the mismatch between modelled and observed $\mathrm{CH}_{4}$ mixing ratios and presented in Sect. 3.2 is calculated from measurements at five remote stations. Some uncertainty exists in these terms due to possible observational uncertainty and shortcomings of the nudging procedure. An indication of the observational uncertainty is given in Fig. 4, where two observationbased estimates of the global mean $\mathrm{CH}_{4}$ growth rate variations are shown. The GLOBALVIEW data use a more complete set of stations, but might contain measurements affected by nearby emissions. Furthermore, additional processing is done to gap-fill and homogenise the station data. The two estimates are in good agreement except for the year 1991, where they differ by about $4 \mathrm{ppb} \mathrm{yr}^{-1}$. Some uncertainty also exists in the timing and location of the missing emission variations given by the nudging term. Our nudging procedure is in general able to capture the global growth rate variations. However, because the nudging corrects the amount of $\mathrm{CH}_{4}$ in the zonal band where the mismatch occurs, this procedure does not account for sub-monthly transport between zonal bands. An inverse modelling set-up would be needed to exploit all available measurements to better resolve the sources of mismatch.

\section{Conclusions}

The processes responsible for $\mathrm{CH}_{4}$ variability in the early 1990s have been investigated in the TM5 global chemistry and transport model. Known drivers of $\mathrm{CH}_{4}$ variations include (i) photochemical effects of stratospheric sulfur from Pinatubo and (ii) of stratospheric $\mathrm{O}_{3}$ changes, (iii) temperature and humidity perturbations, and their effect on $\mathrm{CH}_{4}$ chemistry, (iv) variations in $\mathrm{CH}_{4}$ emissions from wetlands, (v) biomass burning and (vi) anthropogenic sources, and (vii) changes in emissions of other compounds and their effect on $\mathrm{OH}$. We find that all these processes contributed in a significant way to the $\mathrm{CH}_{4}$ growth rate variations in the early 1990s.

The "explained" growth rate evolution falls within the observational range during 1991. However, the increase in growth rate modelled at the end of 1991 using wetlands $\mathrm{CH}_{4}$ emissions from LPJ is not found in the observations. The observed decrease of about $10 \mathrm{ppbyr}^{-1}$ in $\mathrm{CH}_{4}$ growth rate during the year 1992 is captured by the model with a delay of half a year to 1 year. We have used two inventories for $\mathrm{CH}_{4}$ emission from wetlands to explore the potential role of uncertainties in this emission sector. Although they have a significantly different variability, the two inventories give a similar performance in capturing the global $\mathrm{CH}_{4}$ variations. 
When using ORCHIDEE, the global $\mathrm{CH}_{4}$ growth rate is better captured in 1990 to 1993, while using LPJ we are able to reproduce better the $\mathrm{CH}_{4}$ growth rate at the end of the analysed period. The increase in $\mathrm{CH}_{4}$ in 1993 is not captured by either of the two scenarios. According to our breakdown in individual causes for $\mathrm{CH}_{4}$ growth rate changes, the overall decrease in the $\mathrm{CH}_{4}$ growth rate of $5 \mathrm{ppb} \mathrm{yr}^{-1}$ during 1990 to 1995 is explained by the observed decrease in $\mathrm{O}_{3}$ column due to the 11-year cycle in solar activity, and by the estimated decrease in $\mathrm{CO}$ and NMVOC emissions in this period.

By analysing the nudging term, we find that the mismatch most likely originates in the northern tropical region. Since the effects of UV changes and temperature changes on $\mathrm{OH}$ are considered to be robust, the most likely source of missing variability are natural $\mathrm{CH}_{4}$ emissions from wetlands. Uncertainties in tropical biomass burning emissions, and in biogenic NMVOC emissions and their effect on $\mathrm{OH}$, might have also contributed to the mismatch between the modelled and observed $\mathrm{CH}_{4}$ concentrations. Modelling $\mathrm{CH}_{4}$ emissions from wetlands is a challenging topic, due to the large spatial and temporal variability of these ecosystems. The large differences between the two emission data sets used here in terms of $\mathrm{CH}_{4}$ emission amount and variability show that further research is needed to understand the factors driving emissions from wetlands and their response to environmental factors. Furthermore, the effect of changes in diffuse radiation and sulfur deposition after the eruption are not taken into account in the inventories used in this study. Another source of uncertainty are changes in NMVOC emissions, as well as the impact of NMVOC changes on OH. Further study is recommended using an updated isoprene chemistry scheme that considers the $\mathrm{OH}$ recycling by NMVOC, and using NMVOC emission models that take into account the effect of both direct and diffuse radiation. Finally, some uncertainty exists in our nudging procedure. An inverse modelling approach using $\mathrm{OH}$ fields from this study and all available $\mathrm{CH}_{4}$ station measurement data could better resolve the sources and timing of model-measurement mismatch. This might, almost 25 years after the Pinatubo eruption, further improve our knowledge of the drivers of $\mathrm{CH}_{4}$ growth rate variations. 
Appendix A: Validation of the two-step nudging set-up
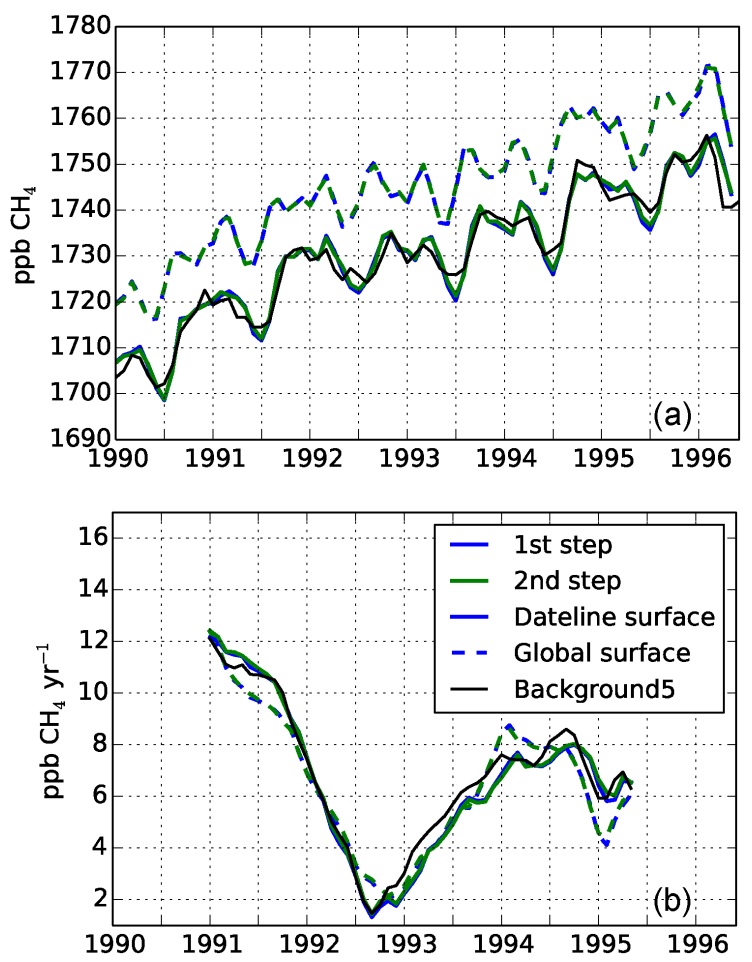

Figure A1. Surface mean $\mathrm{CH}_{4}$ (a) concentrations and (b) growth rate for the two runs of the Base1 simulation at the dateline (solid lines) and global mean (dashed lines). The black line shows the background mean concentrations based on five background stations.

We use a two-step method to simulate realistic $\mathrm{CH}_{4}$ concentrations. In a first step, Base1 and Base2 scenarios are run with near-surface $\mathrm{CH}_{4}$ mixing ratios nudged towards the zonal mean background mixing ratios inferred from measurements at the five stations of South Pole, Cape Grim, Mauna Loa, Niwot Ridge, and Barrow. The nudging amount is stored on a monthly basis for each $10^{\circ}$ latitude band, and used in the second step. In this second step, $\mathrm{CH}_{4}$ is no longer constrained by observations, but instead the nudging amount calculated in the first step is applied as an emission in all scenarios in the lower $2 \mathrm{~km}$.

Figure A1 presents the global and dateline monthly mean $\mathrm{CH}_{4}$ concentrations and the deseasonalised growth rates obtained in the two runs of Base1, and their comparison with Background5 observations. Please note that we show here absolute $\mathrm{CH}_{4}$ growth rates, and not variations with respect to 1990 as shown in Fig. 4. Also note that the actual $\mathrm{CH}_{4}$ growth rates in Basel are plotted, unlike in Figs. 3 and 4 and where differences between simulations were presented. $\mathrm{CH}_{4}$ concentrations at the dateline were nudged in the first step to the concentration values indicated by Background5. Therefore, the fact that the $\mathrm{CH}_{4}$ dateline mean concentrations follow reasonably well the observations is a result of the nudging procedure. The global surface mean concentrations in the model show similar variations as the dateline mean, but with concentrations of 10 to $15 \mathrm{ppb}$ higher. This is due to the fact that the dateline crosses the Pacific Ocean, and is remote from $\mathrm{CH}_{4}$ sources, while in the global mean both remote and polluted areas are included. The observed deseasonalised $\mathrm{CH}_{4}$ growth rate is well reproduced in the model both by the dateline mean and by the surface mean. The modelled dateline growth rate is within $1 \mathrm{ppb} \mathrm{yr}^{-1}$ from the observed one, while the model global mean is within $2 \mathrm{ppbyr}^{-1}$. Both the surface mean and the dateline mean of the two steps from the model follow well the observed growth rate variations, with a slightly better performance of the dateline towards the end of the simulation.

The global mean and dateline mean concentrations and growth rates of the second step are nearly identical to those of the first step. This shows that the procedure in which the correction is applied does not significantly influence the results, and that the simulation results of the two steps give a similar performance in capturing the observed $\mathrm{CH}_{4}$ growth rates.

\section{Appendix B: Additivity between drivers of $\mathrm{CH}_{4}$ variability}

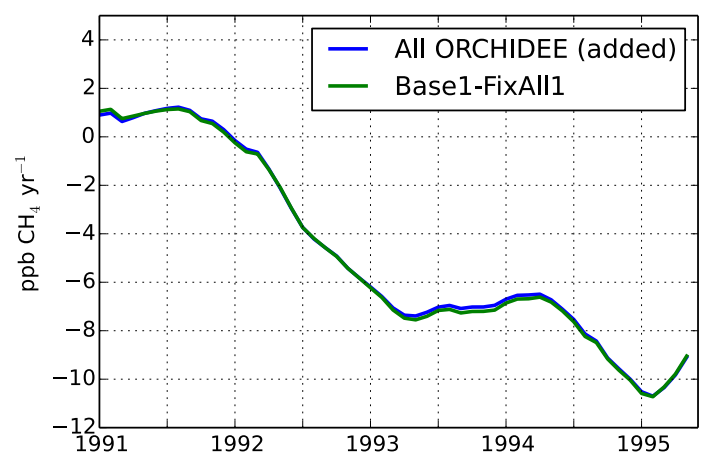

Figure B1. The combined effect of the seven drivers of $\mathrm{CH}_{4}$ variability on the global growth rate using ORCHIDEE emissions, assuming additivity (blue) and from the difference between Base 1 and FixAll1.

In Fig. 3 we have shown the combined effect of the drivers for $\mathrm{CH}_{4}$ variability assuming additivity between the different drivers. We verify this assumption by using results from the FixAll1 simulation, where all drivers of $\mathrm{CH}_{4}$ were fixed to 1990 values. Figure B1 shows the combined effect of the seven drivers for $\mathrm{CH}_{4}$ variability found from the sum of individual drivers for the first simulation set (also shown in Fig. 5.4 and labelled "All Orchidee") and the combined effect found from the difference between Base1 and FixAll1. The two global $\mathrm{CH}_{4}$ growth rate curves nearly overlap each other, with differences less than $0.2 \mathrm{ppb} \mathrm{yr}^{-1}$. This shows that, indeed, the assumption of additivity is valid. 
Acknowledgements. We thank Bruno Ringeval and Joe Melton for providing the ORCHIDEE emission data. This work was supported by the Netherlands Organisation for Scientific Research (NWO). We thank the SURF Foundation (www.surfsara.nl) for their support in using the Dutch national e-infrastructure.

Edited by: P. Jöckel

\section{References}

Aan de Brugh, J. M. J., Schaap, M., Vignati, E., Dentener, F., Kahnert, M., Sofiev, M., Huijnen, V., and Krol, M. C.: The European aerosol budget in 2006, Atmos. Chem. Phys., 11, 1117-1139, doi:10.5194/acp-11-1117-2011, 2011.

Andres, R. J. and Kasgnoc, A. D.: A time-averaged inventory of subaerial volcanic, J. Geophys. Res.h, 103, 25251-25261, doi:10.1029/98JD02091, 1998.

Aquila, V., Oman, L. D., Stolarski, R., Douglass, A. R., and Newman, P. A.: The Response of Ozone and Nitrogen Dioxide to the Eruption of Mt. Pinatubo at Southern and Northern Midlatitudes, J. Atmos. Sci., 70, 894-900, doi:10.1175/JAS-D-120143.1, 2013.

Bândă, N., Krol, M., van Weele, M., van Noije, T., and Röckmann, T.: Analysis of global methane changes after the 1991 Pinatubo volcanic eruption, Atmos. Chem. Phys., 13, 22672281, doi:10.5194/acp-13-2267-2013, 2013.

Bândă, N., Krol, M., van Noije, T., van Weele, M., Williams, J. E., Le Sager, P., Niemeier, U., Thomason, L., and Röckmann, T.: The effect of stratospheric sulfur from Mount Pinatubo on tropospheric oxidizing capacity and methane, J. Geophys. Res.Atmos., 120, 2014JD022137, doi:10.1002/2014JD022137, 2014.

Bekki, S. and Law, K. S.: Sensitivity of the atmospheric CH4 growth rate to global temperature changes observed from 1980 to 1992, Tellus, 49B, 409-416, 1997.

Bekki, S. and Pyle, J. A.: A two-dimensional modeling study of the volcanic eruption of Mount Pinatubo, J. Geophys. Res., 99, 18861-18869, 1994.

Bekki, S., Law, K. S., and Pyle, J. A.: Effect of ozone depletion on atmospheric CH4 and CO concentrations, Nature, 371, 595-597, 1994.

Bousquet, P., Hauglustaine, D. A., Peylin, P., Carouge, C., and Ciais, P.: Two decades of $\mathrm{OH}$ variability as inferred by an inversion of atmospheric transport and chemistry of methyl chloroform, Atmos. Chem. Phys., 5, 2635-2656, doi:10.5194/acp-52635-2005, 2005.

Bousquet, P., Ciais, P., Miller, J. B., Dlugokencky, E. J., Hauglustaine, D. A., Prigent, C., Van der Werf, G. R., Peylin, P., Brunke, E.-G., Carouge, C., Langenfelds, R. L., Lathière, J., Papa, F., Ramonet, M., Schmidt, M., Steele, L. P., Tyler, S. C., and White, J.: Contribution of anthropogenic and natural sources to atmospheric methane variability, Nature, 443, 439-43, doi:10.1038/nature05132, 2006.

Dalsøren, S. B. and Isaksen, I. S. A.: CTM study of changes in tropospheric hydroxyl distribution 1990-2001 and its impact on methane, Geophys. Res. Lett., 33, L23811, doi:10.1029/2006GL027295, 2006.

Dee, D. P., Uppala, S. M., Simmons, A. J., Berrisford, P., Poli, P., Kobayashi, S., Andrae, U., Balmaseda, M. A., Balsamo, G.,
Bauer, P., Bechtold, P., Beljaars, A. C. M., Berg, L. V. D., Bidlot, J., Bormann, N., Delsol, C., Dragani, R., Fuentes, M., Geer, A. J., Haimberger, L., Healy, S. B., Hersbach, H., Holm, E. V., Isaksen, L., and Kallberg, P.: The ERA-Interim reanalysis : configuration and performance of the data assimilation system, Q. J. Roy. Meteorol. Soc., 137, 553-597, doi:10.1002/qj.828, 2011.

Denman, K., Brasseur, G., Chidthaisong, A., Ciais, P., Cox, P., Dickinson, R., Hauglustaine, D., Heinze, C., Holland, E., Jacob, D., Lohmann, U., Ramachandran, S., Dias, P. D. S., Wofsy, S., and Zhang, X.: Couplings Between Changes in the Climate System and Biogeochemistry, in: Climate Change 2007: The Physical Science Basis. Contribution of Working Group I to the Fourth Assessment Report of the Intergovernmental Panel on Climate Change, Tech. rep., Cambridge University Press, Cambridge, United Kingdom and New York, NY, USA, 2007.

Dentener, F., Peters, W., Krol, M., Weele, M. V., and Bergamaschi, P.: Interannual variability and trend of $\mathrm{CH} 4$ lifetime as a measure for OH changes in the 1979-1993 time period, J. Geophys. Res., 108, D15, doi:10.1029/2002JD002916, 2003.

Dessler, A. E., Schoeberl, M. R., Wang, T., Davis, S. M., Rosenlof, K. H., and Vernier, J.-P.: Variations of stratospheric water vapor over the past three decades, J. Geophys. Res.-Atmos., 119, 12588-12598, doi:10.1002/2014JD021712, 2014.

Dlugokencky, E. J., Masaire, K. A., Lang, P. M., Tans, P. P., Steele, L. P., and Nisbet, E. G.: A dramatic decrease in the growth rate of atmospheric methane in the northern hemisphere during 1992, Geophys. Res. Lett., 21, 45-48, 1994.

Dlugokencky, E. J., Dutton, E. G., Novelli, P. C., Tans, P. P., Masarie, K. A., Lantz, K. O., and Madronich, S.: Changes in $\mathrm{CH}_{4}$ and $\mathrm{CO}$ growth rates after the eruption of Mt. Pinatubo and their link with changes in tropical tropospheric UV flux, Geophys. Res. Lett., 23, 2761-2764, 1996.

Dunfield, P., Knowles, R., Dumont, R., and Moore, T. R.: Methane production and consumption in temperate and subarctic peat soils: Response to temperature and pH, Soil Biol. Biochem., 25, 321-326, doi:10.1016/0038-0717(93)90130-4, 1993.

Gauci, V. and Chapman, S. J.: Simultaneous inhibition of CH4 efflux and stimulation of sulphate reduction in peat subject to simulated acid rain, Soil Biol. Biochem., 38, 3506-3510, doi:10.1016/j.soilbio.2006.05.011, 2006.

Gauci, V., Blake, S., Stevenson, D. S., and Highwood, E. J.: Halving of the northern wetland $\mathrm{CH} 4$ source by a large Icelandic volcanic eruption, J. Geophys. Res., 113, 1-8, doi:10.1029/2007JG000499, 2008.

GLOBALVIEW-CH4: Cooperative Atmospheric Data Integration Project - Methane, CD-ROM, NOAA ESRL, Boulder, Colorado, also available via anonymous FTP to ftp://ftp.cmdl.noaa.gov, Path: ccg/ch4/GLOBALVIEW, 2009.

Grooß, J.-U. and Russell III, James M.: Technical note: A stratospheric climatology for $\mathrm{O}_{3}, \mathrm{H}_{2} \mathrm{O}, \mathrm{CH}_{4}, \mathrm{NO}_{\mathrm{x}}, \mathrm{HCl}$ and $\mathrm{HF}$ derived from HALOE measurements, Atmos. Chem. Phys., 5, 2797-2807, doi:10.5194/acp-5-2797-2005, 2005.

Guo, S., Bluth, G. J. S., Rose, W. I., Watson, I. M., and Prata, A. J.: Re-evaluation of SO2 release of the 15 June 1991 Pinatubo eruption using ultraviolet and infrared satellite sensors, Geochem. Geophys. Geosyst., 5, Q04001, doi:10.1029/2003GC000654, 2004. 
Houweling, S., Dentener, F., and Lelieveld, J.: The impact of nonmethane hydrocarbon compounds on tropospheric photochemistry radical, J. Geophys. Res., 103, 10673-10696, 1998.

Huijnen, V., Williams, J., van Weele, M., van Noije, T., Krol, M., Dentener, F., Segers, A., Houweling, S., Peters, W., de Laat, J., Boersma, F., Bergamaschi, P., van Velthoven, P., Le Sager, P., Eskes, H., Alkemade, F., Scheele, R., Nédélec, P., and Pätz, H.-W.: The global chemistry transport model TM5: description and evaluation of the tropospheric chemistry version 3.0, Geosci. Model Dev., 3, 445-473, doi:10.5194/gmd-3-445-2010, 2010.

Huijnen, V., Williams, J. E., and Flemming, J.: Modeling global impacts of heterogeneous loss of $\mathrm{HO}_{2}$ on cloud droplets, ice particles and aerosols, Atmos. Chem. Phys. Discuss., 14, 8575-8632, doi:10.5194/acpd-14-8575-2014, 2014.

Kirschke, S., Bousquet, P., Ciais, P., Saunois, M., Canadell, J. G., Dlugokencky, E. J., Bergamaschi, P., Bergmann, D., Blake, D. R., Bruhwiler, L., Cameron-Smith, P., Castaldi, S., Chevallier, F., Feng, L., Fraser, A., Heimann, M., Hodson, E. L., Houweling, S., Josse, B., Fraser, P. J., Krummel, P. B., Lamarque, J.-F., Langenfelds, R. L., Le Quéré, C., Naik, V., O’Doherty, S., Palmer, P. I., Pison, I., Plummer, D., Poulter, B., Prinn, R. G., Rigby, M., Ringeval, B., Santini, M., Schmidt, M., Shindell, D. T., Simpson, I. J., Spahni, R., Steele, L. P., Strode, S. a., Sudo, K., Szopa, S., van der Werf, G. R., Voulgarakis, A., van Weele, M., Weiss, R. F., Williams, J. E., and Zeng, G.: Three decades of global methane sources and sinks, Na. Geosci., 6, 813-823, doi:10.1038/ngeo1955, 2013

Lamarque, J.-F., Bond, T. C., Eyring, V., Granier, C., Heil, A., Klimont, Z., Lee, D., Liousse, C., Mieville, A., Owen, B., Schultz, M. G., Shindell, D., Smith, S. J., Stehfest, E., Van Aardenne, J., Cooper, O. R., Kainuma, M., Mahowald, N., McConnell, J. R., Naik, V., Riahi, K., and van Vuuren, D. P.: Historical (1850-2000) gridded anthropogenic and biomass burning emissions of reactive gases and aerosols: methodology and application, Atmos. Chem. Phys., 10, 7017-7039, doi:10.5194/acp10-7017-2010, 2010.

Law, K. S. and Nisbet, E. G.: Sensitivity of the $\mathrm{CH}_{4}$ growth rate to changes in $\mathrm{CH}_{4}$ emissions from natural gas and coal, J. Geophys. Res., 101, 14387-14397, 1996.

Lawrence, M. G., Jöckel, P., and von Kuhlmann, R.: What does the global mean $\mathrm{OH}$ concentration tell us?, Atmos. Chem. Phys., 1, 37-49, doi:10.5194/acp-1-37-2001, 2001.

Lelieveld, J., Peters, W., Dentener, F. J., and Krol, M. C.: Stability of tropospheric hydroxyl chemistry, J. Geophys. Res., 107, 4715, doi:10.1029/2002JD002272, 2002.

McCormick, M. P., Thomason, L. W., and Trepte, C. R.: Atmospheric effects of the Mt. Pinatubo eruption, Nature, 373, 399404, 1995

Melton, J. R., Wania, R., Hodson, E. L., Poulter, B., Ringeval, B., Spahni, R., Bohn, T., Avis, C. A., Beerling, D. J., Chen, G., Eliseev, A. V., Denisov, S. N., Hopcroft, P. O., Lettenmaier, D. P., Riley, W. J., Singarayer, J. S., Subin, Z. M., Tian, H., Zürcher, S., Brovkin, V., van Bodegom, P. M., Kleinen, T., Yu, Z. C., and Kaplan, J. O.: Present state of global wetland extent and wetland methane modelling: conclusions from a model intercomparison project (WETCHIMP), Biogeosciences, 10, 753788, doi:10.5194/bg-10-753-2013, 2013.

Mercado, L. M., Bellouin, N., Sitch, S., Boucher, O., Huntingford, C., Wild, M., and Cox, P. M.: Impact of changes in diffuse ra- diation on the global land carbon sink, Nature, 458, 1014-1018, doi:10.1038/nature07949, 2009.

Metzger, S., Dentener, F., Pandis, S., and Lelieveld, J.: Gas/aerosol partitioning: 1. A computationally efficient model, Journal of Geophysical Research: Atmospheres, 107, ACH 16-1-ACH 1624, doi:10.1029/2001JD001102, 2002.

Montzka, S. A., Dlugokencky, E. J., and Butler, J. H.: Non$\mathrm{CO}_{2}$ greenhouse gases and climate change, Nature, 476, 43-50, doi:10.1038/nature10322, 2011.

Niemeier, U., Timmreck, C., Graf, H.-F., Kinne, S., Rast, S., and Self, S.: Initial fate of fine ash and sulfur from large volcanic eruptions, Atmos. Chem. Phys., 9, 9043-9057, doi:10.5194/acp9-9043-2009, 2009.

Patra, P. K., Krol, M. C., Montzka, S. A., Arnold, T., Atlas, E. L., Lintner, B. R., Stephens, B. B., Xiang, B., Elkins, J. W., Fraser, P. J., Ghosh, A., Hintsa, E. J., Hurst, D. F., Ishijima, K., Krummel, P. B., Miller, B. R., Miyazaki, K., Moore, F. L., O’Doherty, S., Prinn, R. G., Steele, L. P., Takigawa, M., Wang, H. J., Weiss, R. F., Wofsy, S. C., and Young, D.: Observational evidence for interhemispheric hydroxyl-radical parity, Nature, 513, 219-223, doi:10.1038/nature13721, 2014.

Pison, I., Ringeval, B., Bousquet, P., Prigent, C., and Papa, F.: Stable atmospheric methane in the 2000s: key-role of emissions from natural wetlands, Atmos. Chem. Phys., 13, 11609-11623, doi:10.5194/acp-13-11609-2013, 2013.

Pöschl, U., von Kuhlmann, R., Poisson, N., and Crutzen, P.: Development and Intercomparison of Condensed Isoprene Oxidation Mechanisms for Global Atmospheric Modeling, J. Atmos. Chem., 37, 29-52, doi:10.1023/A:1006391009798, 2000.

Prinn, R. G., Huang, J., Weiss, R. F., Cunnold, D. M., Fraser, P. J., Simmonds, P. G., McCulloch, A., Harth, C., Reimann, S., Salameh, P., O’Doherty, S., Wang, R. H. J., Porter, L. W., Miller, B. R., and Krummel, P. B.: Evidence for variability of atmospheric hydroxyl radicals over the past quarter century, Geophys. Res. Lett., 32, L07809, doi:10.1029/2004GL022228, 2005.

Ringeval, B., de Noblet-Ducoudré, N., Ciais, P., Bousquet, P., Prigent, C., Papa, F., and Rossow, W. B.: An attempt to quantify the impact of changes in wetland extent on methane emissions on the seasonal and interannual time scales, Global Biogeochem. Cy., 24, GB2003, doi:10.1029/2008GB003354, 2010.

Rohrer, F., Lu, K., Hofzumahaus, A., Bohn, B., Brauers, T., Chang, C.-C., Fuchs, H., Haseler, R., Holland, F., Hu, M., Kita, K., Kondo, Y., Li, X., Lou, S., Oebel, A., Shao, M., Zeng, L., Zhu, T., Zhang, Y., and Wahner, A.: Maximum efficiency in the hydroxylradical-based self-cleansing of the troposphere, Nat. Geosci., 7, 559-563, 2014.

Schauffler, S. M. and Daniel, J. S.: On the effects of stratospheric circulation changes on trace gas trends, J. Geophys. Res., 99, 25747-25754, 1994.

Schultz, M. G., Heil, A., Hoelzemann, J. J., Spessa, A., Thonicke, K., Goldammer, J. G., Held, A. C., Pereira, J. M. C., and van het Bolscher, M.: Global wildland fire emissions from 1960 to 2000, Global Biogeochem. Cy., 22, GB2002, doi:10.1029/2007GB003031, 2008.

Shepherd, T. G., Plummer, D. A., Scinocca, J. F., Hegglin, M. I., Fioletov, V. E., Reader, M. C., Remsberg, E., von Clarmann, T., and Wang, H. J.: Reconciliation of halogen-induced ozone loss with the total-column ozone record, Nat. Geosci., 7, 443-449, doi:10.1038/ngeo2155, 2014. 
Sindelarova, K., Granier, C., Bouarar, I., Guenther, A., Tilmes, S., Stavrakou, T., Müller, J.-F., Kuhn, U., Stefani, P., and Knorr, W.: Global data set of biogenic VOC emissions calculated by the MEGAN model over the last 30 years, Atmos. Chem. Phys., 14, 9317-9341, doi:10.5194/acp-14-9317-2014, 2014.

Soden, B. J., Wetherald, R. T., Stenchikov, G. L., and Robock, A.: Global Cooling After the Eruption of Mount Pinatubo: A Test of Climate Feedback by Water Vapor, Science, 296, 727-730, doi:10.1126/science.296.5568.727, 2002.

Spahni, R., Wania, R., Neef, L., van Weele, M., Pison, I., Bousquet, P., Frankenberg, C., Foster, P. N., Joos, F., Prentice, I. C., and van Velthoven, P.: Constraining global methane emissions and uptake by ecosystems, Biogeosciences, 8, 1643-1665, doi:10.5194/bg8-1643-2011, 2011.

Stone, D., Evans, M. J., Edwards, P. M., Commane, R., Ingham, T., Rickard, A. R., Brookes, D. M., Hopkins, J., Leigh, R. J., Lewis, A. C., Monks, P. S., Oram, D., Reeves, C. E., Stewart, D., and Heard, D. E.: Isoprene oxidation mechanisms: measurements and modelling of $\mathrm{OH}$ and $\mathrm{HO}_{2}$ over a South-East Asian tropical rainforest during the OP3 field campaign, Atmos. Chem. Phys., 11, 6749-6771, doi:10.5194/acp-11-6749-2011, 2011.

Telford, P., Braesicke, P., Morgenstern, O., and Pyle, J.: Reassessment of causes of ozone column variability following the eruption of Mount Pinatubo using a nudged CCM, Atmos. Chem. Phys., 9, 4251-4260, doi:10.5194/acp-9-4251-2009, 2009.

Telford, P. J., Lathière, J., Abraham, N. L., Archibald, A. T., Braesicke, P., Johnson, C. E., Morgenstern, O., O'Connor, F. M., Pike, R. C., Wild, O., Young, P. J., Beerling, D. J., Hewitt, C. $\mathrm{N}$., and Pyle, J.: Effects of climate-induced changes in isoprene emissions after the eruption of Mount Pinatubo, Atmos. Chem. Phys., 10, 7117-7125, doi:10.5194/acp-10-7117-2010, 2010.

Tiedtke, M.: A comprehensive mass flux scheme for cumulus parameterization in large-scale models, Mon. Weather Rev., 117, 1779-1800, 1989.

van $\operatorname{der}$ A, R. J., Allaart, M. A. F., and Eskes, H. J.: Multi sensor reanalysis of total ozone, Atmos. Chem. Phys., 10, 11277-11294, doi:10.5194/acp-10-11277-2010, 2010.

van Noije, T. P. C., Le Sager, P., Segers, A. J., van Velthoven, P. F. J., Krol, M. C., Hazeleger, W., Williams, A. G., and Chambers, S. D.: Simulation of tropospheric chemistry and aerosols with the climate model EC-Earth, Geosci. Model Dev., 7, 2435-2475, doi:10.5194/gmd-7-2435-2014, 2014.
Vignati, E., Wilson, J., and Stier, P.: M7: An efficient sizeresolved aerosol microphysics module for large-scale aerosol transport models, J. Geophys. Res.-Atmos., 109, D22202, doi:10.1029/2003JD004485, 2004.

Vignati, E., Facchini, M., Rinaldi, M., Scannell, C., Ceburnis, D., Sciare, J., Kanakidou, M., Myriokefalitakis, S., Dentener, F., and O'Dowd, C.: Global scale emission and distribution of sea-spray aerosol: Sea-salt and organic enrichment, Atmos. Environ., 44, 670-677, doi:10.1016/j.atmosenv.2009.11.013, 2010.

Wang, J. S., Logan, J. A., Mcelroy, M. B., Duncan, B. N., Megretskaia, I. A., and Yantosca, R. M.: A 3-D model analysis of the slowdown and interannual variability in the methane growth rate from 1988 to 1997, Global Biogeochem. Cy., 18, GB3011, doi:10.1029/2003GB002180, 2004.

Wania, R., Melton, J. R., Hodson, E. L., Poulter, B., Ringeval, B., Spahni, R., Bohn, T., Avis, C. A., Chen, G., Eliseev, A. V., Hopcroft, P. O., Riley, W. J., Subin, Z. M., Tian, H., van Bodegom, P. M., Kleinen, T., Yu, Z. C., Singarayer, J. S., Zürcher, S., Lettenmaier, D. P., Beerling, D. J., Denisov, S. N., Prigent, C., Papa, F., and Kaplan, J. O.: Present state of global wetland extent and wetland methane modelling: methodology of a model inter-comparison project (WETCHIMP), Geosci. Model Dev., 6, 617-641, doi:10.5194/gmd-6-617-2013, 2013.

Williams, J. E., Landgraf, J., Bregman, A., and Walter, H. H.: A modified band approach for the accurate calculation of online photolysis rates in stratospheric-tropospheric Chemical Transport Models, Atmos. Chem. Phys., 6, 4137-4161, doi:10.5194/acp-6-4137-2006, 2006.

Williams, J. E., Strunk, A., Huijnen, V., and van Weele, M.: The application of the Modified Band Approach for the calculation of on-line photodissociation rate constants in TM5: implications for oxidative capacity, Geosci. Model Dev., 5, 15-35, doi:10.5194/gmd-5-15-2012, 2012.

Wilton, D. J., Hewitt, C. N., and Beerling, D. J.: Simulated effects of changes in direct and diffuse radiation on canopy scale isoprene emissions from vegetation following volcanic eruptions, Atmos. Chem. Phys., 11, 11723-11731, doi:10.5194/acp11-11723-2011, 2011. 